\title{
Relationships between circulating plasma concentrations and duodenal flows of essential amino acids in lactating dairy cows
}

\author{
R. A. Patton,${ }^{* 1}$ A. N. Hristov, $\dagger$ C. Parys,$\ddagger$ and H. Lapierre \\ *Nittany Dairy Nutrition Inc., Mifflinburg, PA 17844 \\ †Department of Animal Science, The Pennsylvania State University, University Park, 16802 \\ łEvonik Industries, AG, 63457 Hanau, Germany \\ $\S$ Dairy and Swine Research and Development Centre, Agriculture and Agri-Food Canada, Sherbrooke, Quebec, Canada J1M 0C8
}

\section{ABSTRACT}

The objective of this study was to better define essential AA (EAA) requirements in lactating dairy cows through examination of the relationship between plasma essential AA concentration (p[EAA]) and predicted duodenal flow of essential AA (EAAduo). Our hypothesis was that at a given level of milk protein output, $p$ [EAA] would remain steady in response to increasing EAAduo until the EAA requirement was met, at which point $\mathrm{p}[\mathrm{EAA}]$ would increase rapidly in response to greater duodenal flow of EAA until p[EAA] reached a plateau as other body processes degraded excess EAA to avoid toxicity. Thus, the requirement of each EAA would be fulfilled when $\mathrm{p}[\mathrm{EAA}]$ increased rapidly. To investigate this hypothesis, we compiled a literature database that included 102 studies with 420 treatment means that reported $\mathrm{p}[\mathrm{EAA}]$, dietary nutrient content, body weight, and milk production. A second database was produced to validate relationships developed in the first database and included 32 studies with 98 treatment means. All relationships were evaluated as regression equations with study as a random factor. Breed, days in milk, body weight, and milk protein production had no effect on the plasma concentration of any EAA. Other than metabolizable protein supply, nutritional content of the rations did not affect $\mathrm{p}[\mathrm{EAA}]$. Only $\mathrm{p}[\mathrm{Arg}]$ was affected by parity, with primiparous cows having higher concentrations of Arg than older cows. No break points in the relationship between $\mathrm{p}[\mathrm{EAA}]$ versus EAAduo were detected as either steep increases or plateaus. Plasma Arg, Ile, Lys, Thr, and Val concentrations were best associated with their respective EAAduo as quadratic equations, whereas His, Leu, Met, and Phe were associated only linearly. Adding a quadratic term improved the adjusted $\mathrm{R}^{2}$ or decreased the root mean square error marginally $(<2.0 \%)$. Thus, we conclude that the main effect of EAAduo on $\mathrm{p}[\mathrm{EAA}]$ is linear. Abomasal

Received October 21, 2014.

Accepted March 2, 2015.

${ }^{1}$ Corresponding author: nittnut@aol.com or duodenal infusions of Met, Lys, His, Lys+Met, and casein revealed that Met or Lys infused alone increased the plasma concentration of the infused EAA and lowered the concentration of other EAA, particularly His. Infusion of Lys+Met or His alone was associated with increases in concentrations of these EAA without affecting others. We conclude that over a wide range of protein intakes in lactating cows, plasma levels of EAA increase linearly with duodenal flow. No evidence was found that EAA requirements are reflected in blood plasma concentrations.

Key words: plasma amino acid, dietary amino acid

\section{INTRODUCTION}

A better understanding of the metabolism of EAA by the lactating dairy cow is necessary to improve efficiency of their transfer to milk protein, thereby increasing $\mathrm{N}$ efficiency and reducing the amount of $\mathrm{N}$ excreted into the environment. Milk protein secretion is the major net user of absorbed AA (Lapierre et al., $2012 \mathrm{~b}$ ). The direct precursors of mammary milk protein synthesis are preformed free AA extracted from blood arterial supply by lactating mammary cells (Linzell, 1974). Broderick et al. (1974) have proposed that variations of plasma essential AA concentration ( $\mathbf{p}[\mathbf{E A A}])$ could be used as a method of identifying limiting EAA, similar to the methodology used in humans and monogastric animals (Garlick, 1980). This method assumes that an EAA concentration builds up in blood plasma only after the requirement for all uses has been fulfilled. Indeed, although it has been reported in both monogastrics (e.g., humans; Moore et al., 2009) and in dairy cows (e.g., Raggio et al., 2006) that increased supply of EAA increased oxidation of Leu as well as increased $\mathrm{p}[\mathrm{Leu}]$. This suggests that the point where a specific EAA concentration begins to increase could indicate the supply at which this EAA requirement is fulfilled, but this was not detected by Broderick et al. (1974) due either to the range of EAA supply relative to the requirements or to the limited number of animals. 
Although many studies with dairy cows reported changes in $\mathrm{p}[\mathrm{EAA}]$ when evaluating the effects of dietary protein changes or additions of rumen protected AA, few studies simultaneously measured duodenal EAA flow (EAAduo) and p[EAA] (e.g., only 2 out of the 40 studies in the database used by Pacheco et al., 2012). This severely limits the number of studies available to examine the relationship between EAAduo and $\mathrm{p}[\mathrm{EAA}]$ in lactating dairy cows. Also, in addition to the fact that collecting duodenal flow information requires invasive and costly surgery, the latter may also in itself produce biases in the measurements. Recently the models used in several ration balancing programs to predict the duodenal flow of protein and EAA have been shown to yield predictions with acceptable accuracy and precision (Pacheco et al., 2012). Therefore, using predictions of duodenal flow rather than direct measurement would make it possible to use the data from a large number of existing studies reporting $\mathrm{p}[\mathrm{EAA}]$. In turn, this could allow for more clearly defined relationships between EAAduo and p[EAA] and may ultimately help to better define EAA requirements. Furthermore, few studies have specifically examined potential factors (e.g., cow breed, BW, stage of lactation, parity, and nutrient density of the diet) that may potentially alter the relationships between AA supply and p[EAA]. For example, it has been suggested that conversion of EAA to milk protein by the mammary gland is negatively affected by increased DIM (Yeo et al., 2003), although this observation has not been confirmed by others (Dalbach et al., 2011). Likewise, it has been postulated that greater dietary energy density increases the transfer of Met from duodenal flow (Metduo) into milk protein (Rulquin and Delaby, 1997), but higher energy did not increase milk protein to a greater extent in response to elevated Met supply (Patton, 2010). A better understanding of the relationship between EAAduo and p[EAA] might help to explain these apparent contradictions. To date, a comprehensive review of the relationship between AA supply and p[EAA] and factors that may affect this relationship has not been performed in lactating dairy cows.

Our hypothesis was that over a wide supply of EAA and a large number of animals, $\mathrm{p}[\mathrm{EAA}]$ in blood plasma would increase slightly or not at all until requirements were met, at which point the concentration would begin to increase significantly. This point of rapid change was postulated as indicating the AA requirement for lactating cows. Therefore, the objectives of the present study were to investigate the relationship between predicted EAAduo and p[EAA] using the meta-analysis approach to detect any nonlinear change in the relationship between $\mathrm{p}[\mathrm{EAA}]$ and EAAduo (break points) as well as to examine the potential effect of cow characteristics (breed, DIM, BW, and milk protein yield) and dietary factors as modifiers of the relationship between $\mathrm{p}[\mathrm{EAA}]$ and EAAduo.

\section{MATERIALS AND METHODS}

The developmental database was collected from a search of lactating cow studies in the Journal of Dairy Science between 1982 and 2012 that reported p[EAA], $\mathrm{BW}$, DMI, and enough ration details so that the nutritional content could be sufficiently reconstructed. Studies from the Journal of Dairy Science were selected for the developmental database because it appeared as though most studies that reported p[EAA] were published here. Studies outside these years, in other refereed journals, or that were initially missed were reserved for the validation database. Studies selected for both databases included feeding trials (including those using rumen-protected AA: RPAA) and infusion experiments wherein a test protein was infused into the abomasum or into the duodenum. When EAA or proteins were infused, the whole quantity of infused EAA was added to the total EAAduo. No distinction was made between abomasal and duodenal infusions; however, studies that infused directly into the bloodstream were excluded. The developmental database contained studies that reported EAA concentration only in plasma because we did not want potential biases in EAA measurement between serum and plasma to affect development of associative equations. Studies that reported AA concentration in whole blood were excluded, whereas studies that reported AA concentration in serum were used solely in the validation database. The final database used for the developmental analysis contained 104 studies that represented 420 treatment means (Appendix A), whereas the validation database contained 32 studies and 106 treatment means (Appendix B).

Diets were entered into the AminoCow Dairy Ration Evaluator, version 3.5.2 (Evonik Industries AG, Hanau, Germany) for estimating daily EAAduo and MP using the approach previously reported (Patton, 2010; Pacheco et al., 2012). AminoCow was chosen over NRC (2001) because of a more comprehensive feeds library, a slightly more accurate prediction of EAAduo, and author familiarity. Briefly, when ingredient analysis was provided, the corresponding ingredient from the feed database was adjusted to this analysis. For studies that reported the nutrient content of some feeds and not others, the nutrient content for those analyzed were entered and those unanalyzed ingredients were adjusted to agree with the total reported ration analyses. For those studies where only the total ration analysis was reported, the ingredients were adjusted by first adjusting the forages to a maximum of $\pm 20 \%$ of the program 
default for a nutrient. If this level of adjustment could not match the reported analyses, the concentrate portion of the ration was then adjusted until nutritional agreement with the reported total nutrient content in the study was obtained. For the developmental database, 40 of 106 studies (37.7\% of total studies) and 156 of 420 rations (37.1\% of total) reported only total nutrient content of the diets, whereas $66(62.2 \%)$ studies representing 264 treatment means $(62.8 \%)$ reported nutritional content of ingredients as well as nutritional content of total diets. The validation database percentages were similar with 11 of 32 studies $(34.4 \%)$ representing 42 of $106(37.1 \%)$ dietary means reporting dietary nutrient composition, and $66(62.2 \%)$ studies and 264 diets reporting both nutrient composition of diets as well as individual ingredients. The program option to adjust the microbial protein production for a deficiency of MP was always employed, with the exception that when predicted MP deficiency was greater than $600 \mathrm{~g}$, the decrease was maintained at that level as suggested by the studies of Pacheco et al. (2012). Recorded ration nutrients included DMI $(\mathrm{kg} / \mathrm{d}), \mathrm{NE}_{1}$ ( $\mathrm{MCal} / \mathrm{kg})$, total $\mathrm{NE}_{1}$ intake $(\mathrm{MCal} / \mathrm{d}), \mathrm{CP}, \mathrm{NDF}$, ash, crude fat, and NFC (\% of DM) as well as RUP and RDP (\% CP). Net energy of lactation was calculated according to NRC (2001) by selecting this option in the AminoCow program. Also included in the database were the duodenal flows of Arg, His, Ile, Leu, Lys, Met, Phe, Thr, and Val (g/d) as estimated by the AminoCow model. Thus, individual EAA are presented as duodenal flow with no digestibility or bio-availability calculated. For calculation of MP supply, digestibility of both essential and nonessential individual AA was assumed to be $80 \%$ for intact proteins, $90 \%$ for RPAA with level of protection as specified by the product manufacturer, and $100 \%$ for infused AA (Lapierre et al., 2012b). As defined for the AminoCow model, MP is comprised of RUP of individual feeds $\times$ digestibility (including RPAA) plus microbial true protein $\times 80 \%$ digestibility and an estimation of endogenous protein based on $1.9 \mathrm{~g}$ of N/kg of DMI (Swanson, 1977). The grams of endogenous protein flow are calculated using the calculation of NRC $(2001)$ as DMI $(\mathrm{kg}) \times 1.9$ (g of $\mathrm{N})$. The contribution to digestible protein was calculated as DMI $(\mathrm{kg}) \times 1.9(\mathrm{~g} \mathrm{~N}) \times 6.25 \times 80 \%$ digestibility (AminoCow Help, Evonik AG). In addition to total MP flow, a calculated variable was constructed taking into account the amount of AA secreted as milk protein. This variable (MTP_MPY) is defined as grams of MP supply per day $\div$ true milk protein output per day. Amino acids as \% of MP (AA\%MP) were calculated as duodenal flow of $\mathrm{AA} \times$ digestion coefficients referenced above $\div \mathrm{MP} \times 100$. To assess the effect of increasing duodenal microbial crude protein (MCP) supply on $\mathrm{p}[\mathrm{EAA}]$, microbial digestible protein as a \% of total MP (MDP_MP) was calculated by the following formula: $\mathrm{MDP} \% \mathrm{MP}=(\mathrm{MCP} \times 0.8) / \mathrm{MP} \times 100$.

Cow data included from individual studies were breed, parity, DIM, BW, milk production, milk fat, and milk protein concentration (\%). Unless explicitly stated as true protein (TP), it was assumed that milk protein was reported as milk $\mathrm{CP}$, and milk $\mathrm{CP}$ was converted to $\mathrm{TP}$ as milk $\mathrm{CP} \times 0.93(\mathrm{NRC}, 2001)$. Total milk protein yield was calculated as milk yield $\times$ true milk protein $\% \times 0.01$. Also recorded from individual studies was the average DIM, which was recorded as the DIM at study initiation plus half the study length unless explicitly stated that the period when blood samples were taken was not reported as the average of the study periods. The parity of the experimental cows was recorded as primiparous, multiparous ( $\geq$ second lactation) or mixed parities (primiparous + multiparous). Finally, p[EAA], recorded as $\mu M$, included Arg, His, Ile, Leu, Lys, Met, Phe, Thr, and Val. The database contained samples collected from jugular and tail vessels as well as some from the mammary artery. Finally, smaller databases were constructed combining studies from both the development and the validation databases, which included only studies with infusion of casein (21 comparisons) or increased supply of a single AA via infusion or feeding as RPAA. Data in these studies were for His (8 comparisons), Lys (11 comparisons), Met (34 comparisons), or both Lys and Met (41 comparisons). Insufficient numbers of other studies were available with a single addition or deletion of EAA to develop a rigorous database for other EAA. These databases were used to test the effect of a single AA addition to the duodenal flow on the plasma concentration of the added and other EAA.

Outlier values for $\mathrm{p}[\mathrm{EAA}]$ were assessed by the method of Gill (1976) using $P<0.01$ as the critical value before an observation was deleted from the database. We chose this method because we hoped to observe break points in plasma concentrations, even if they occurred at extreme ends of the database but still in physiological ranges. This method purposely results in exclusion of a limited number of studies. In our case, eliminated values were away from the mean by more than $3.6 \times$ the standard deviation.

Associations among variables in the database were assessed as mixed linear regressions using the JMP edition (version 10) of SAS, employing the Fit Model specification with the REML method and with study specified as a random effect. Other variables were specified as fixed effects (St-Pierre, 2001). Nonsignificant factors were removed from the regression equation in a stepwise manner until all remaining terms except the intercept were significant. For p[EAA], linear and 
quadratic terms were evaluated, whereas for other associations only linear associations were tested. Because it has been shown that D-Met is more slowly metabolized than L-Met, and therefore D-Met accumulates more in plasma compared with L-Met (Lapierre et al., 2012a), separate regression equations were developed for rations where Met was sourced from protein or where Met was sourced as DL-Met either from RPMet or infusion of DL-Met. Besides regressions for EAAduo versus $\mathrm{p}[\mathrm{EAA}]$, equations were developed for $\mathrm{p}[\mathrm{EAA}]$, which included not only EAAduo, but also cow factors and ration factors as described earlier. Where mean differences are presented, probability of difference was assessed using the Tukey honestly significant difference test. Comparisons between equations resulting from associations in the development database with values observed in the validation database were compared using the techniques of Bibby and Toutenburg (1977). Probabilities $\leq 0.01$ will be referred to as highly significant, $0.01<P \leq 0.05$ will be referred to as significant, and probabilities of $0.05<P \leq 0.10$ will be referred to as almost significant in the text.

\section{RESULTS}

\section{Features of the Databases}

The development database is described in terms of the stated purpose of each experiment, experimental design, cow breed, parity, and number of cows in Table 1. The validation database is similarly described in Table 2. Characteristics associated with cows and rations for both databases are detailed in Table 3. Overall, the data are representative of the range of milk production, BW, DIM, and dietary ingredients observed in intensive commercial dairy operations worldwide. Experiments were not weighted in this analysis for 2 reasons: (1) most the studies $(\mathrm{n}=73)$ were of crossover designs, which gives an unfair advantage to these studies when weighted (Lean et al., 2009), and (2) when sufficient studies are included, weighting does not change conclusions (Pacheco et al., 2006). We attempted to determine whether sampling site (coded as mammary artery, jugular vein, or caudal vessels) had an effect on $\mathrm{p}$ [EAA]. No effect of site was observed for any EAA except for $\mathrm{p}[\mathrm{Arg}]$, which displayed both an effect of sampling site $(86.4 \pm 3.1,81.8 \pm 6.4$, and $70.0 \pm 4.3$ for coccygeal, arterial, and jugular samples, respectively; $P<0.05$ for coccygeal vs. jugular samples) and a site $\times$ Argduo interaction. A total of $13 \mathrm{p}[\mathrm{EAA}]$ values were removed from the developmental database as identified as outliers ( 1 observation for Arg, 4 for His, 1 for Ile, 3 for Leu, 2 for Lys, and 2 for Met) as well as 1 Met value for the validation database. Other data from these experi- ments remained in the database. All statistics for the development database were applied with these values being excluded. The development database contained 8 studies and 43 diets with Ayrshire cows, 5 studies and 15 diets with Jersey cows, and 2 studies with 6 diets for mixed breed studies; the remaining studies and diets were with Holstein cows. Non-Holsteins represented $14.4 \%$ of the studies and $15.2 \%$ of treatment means. A total of 1,576 individual cows were sampled. Only primiparous cows were used in 6 studies, whereas 39 studies used both first and older parities, and 57 studies used only mature cows. The validation database contained 2 studies and 9 diets with Ayrshire cows, 2 studies and 4 diets with Norwegian red cows, 1 study and 4 diets with Brown Swiss cows, and 1 study and 5 diets with mixed breeds. For this database, non-Holsteins represented $18.2 \%$ of studies and $20.1 \%$ of treatment means. A total of 450 individual cows are represented in the validation database. None of the studies used only primiparous cows; 17 studies used mixed parities and 15 used mature cows.

Because serum samples were included in the validation database to secure sufficient numbers for an adequate test, a determination for differences in both EAAduo and $\mathrm{p}[\mathrm{EAA}]$ between plasma and serum samples across both developmental and validation databases and within the validation set alone was undertaken. Only p[Arg] was different between plasma and serum samples: 82.9 $\pm 2.4 \mu M$ versus $132.0 \pm 6.0 \mu M(P<0.001)$ for both databases combined, and $70.1 \pm 17.3 \mu M$ versus 123.3 $\pm 9.1 \mu M(P<0.001)$ for the validation database alone for plasma and serum samples, respectively. For this reason, only Arg data from plasma samples in the validation database were evaluated.

In general for the developmental database, EAAduo displayed a CV varying between 18 and $24 \%$, and with the exception of $\mathrm{p}$ [Met] from both protein and DL-Met sources, the p[EAA] displayed a CV of 10 to 16\% (Table 4). Plasma Phe and Thr appear to be held in particularly tight ranges, whereas His, Leu, and Val and especially Met show a wider variation in plasma concentration. Breed had no effect for any $\mathrm{p}[\mathrm{EAA}]$, nor were $\mathrm{p}[\mathrm{EAA}]$ different between treatments administered from changes in the diet or from infusions. The only effect of parity on p[EAA] was for p[Arg], where it was observed that primiparous cows had a greater concentration (104.5 $\mu M, P=0.002)$ compared with mixed parities $(81.2 \mu M)$ and multiparous cows (78.5 $\mu M)$. In general BW, parity and DIM had no effect on $\mathrm{p}[\mathrm{EAA}]$. Although the validation database displayed about the same mean predicted duodenal flow with about the same standard deviation, and the resultant plasma concentrations were also approximately equal, the $\mathrm{CV}$ for $\mathrm{p}[\mathrm{EAA}]$ was larger than the development 
database due to a wider observed range and a lower number of studies.

\section{Duodenal AA Flows and Plasma AA Concentration: Developmental Database}

Relationships between predicted individual duodenal AA flow and respective $\mathrm{p}[\mathrm{EAA}]$ concentration were generally high (Table 5), although the root mean square error (RMSE) as a percent of the mean was always greater than $10 \%$. Of the EAAduo studied, 5 were related to $\mathrm{p}$ [EAAduo] only in a linear manner (Arg, His, Leu, and Met from DL-Met supplementation, and Phe), and 5 were related in both a linear and quadratic manner (Ile, Lys, Met from protein sources, Thr, and Val). The slope of the linear equation for DL-Met sources was approximately twice that of L-Met sources. Over all EAA when both linear and quadratic equations were significant, only a slight statistical efficiency, measured by adjusted $\mathrm{R}^{2}$ (adj $\mathbf{R}^{2}$ ), RMSE, or RMSE as \% mean observed value, was gained by adding the squared term compared with the linear term (Table 5). For the linear regression equations, the intercept as a percent of mean represented over $50 \%$ of the mean for the association of duodenal flow with $\mathrm{p}[\mathrm{Arg}], \mathrm{p}[\mathrm{Thr}]$, and $\mathrm{p}[\mathrm{Phe}]$ and almost $50 \%$ for $\mathrm{p}$ [His], $\mathrm{p}[\mathrm{Ile}]$, and $\mathrm{p}$ [Met] from protein sources. When considering only the linear equations, Val had the largest slope value (1.26), whereas Phe displayed the smallest (0.15). Relationships between $\mathrm{p}[\mathrm{EAA}]$ and their respective duodenal flow also displayed rather low slopes for Arg, Lys, and Met from protein sources. However, besides Val, only Met from DL sources displayed a slope greater than 0.50.

To explore the possibility that duodenal EAA flow expressed as \% of MP (EAA_MP) would show more significant relationships to $\mathrm{p}[\mathrm{EAA}]$ than EAAduo, linear regressions with EAA_MP were developed and the results compared with EAAduo (Table 6). In general, associations between EAA_MP and p[EAA] were remarkably similar to those for EAAduo and $\mathrm{p}[\mathrm{EAA}]$ with the exception of $\mathrm{p}[\mathrm{Il}] \mathrm{e}$ which revealed no association to Ile_MP. When expressed as EAA_MP, Arg, Lys, Met from DL, and Val displayed significant quadratic effects. Only Lys and Val displayed quadratic effects for both EAAduo and EAA_MP, whereas His, Leu, and Thr displayed linear associations only in both systems. As when expressed as EAAduo, for EAA_MP Phe displayed the lowest slope parameter, and Val displayed the largest. In general, however, the intercept term was much smaller for significant associations when duodenal EAA were expressed as EAA_MP than as total flow in grams per day. Likewise, adding a quadratic term made little difference in increasing adj $\mathrm{R}^{2}$ or decreasing RMSE except for Lys whose associated equation was increased more than $2 \%$ when the quadratic term was added.

Because MP was highly correlated with EAAduo for all EAA except Met from DL sources (Table 7), regression models for $\mathrm{p}[\mathrm{EAA}]$ were constructed without terms for MP or other EAA included. Likewise we found that consumption variables, such as DMI, and $\mathrm{NE}_{1}$ consumption were highly correlated with EAAduo, and therefore these variables were also not evaluated in the equations developed. Milk production and milk true protein yield (MPY) were correlated with EAAduo to a moderate degree $\left(\mathrm{R}^{2}<0.55\right)$. These variables were left in subsequent associative equations in hope of finding more relevant association. Correlation between MP and the flow of each individual EAA as well as individual p[EAA] was always highly significant (Table 7). Terms for MTP_MP and MDP_MP were included in evaluations for subsequent factors in regression equations.

\section{Effect of Increasing AA Demand for Milk Protein Production on Plasma Concentration}

Increased production of milk true protein was not associated with increased plasma concentration of Arg, His and Met from DL-Met (Table 8). The p[Lys] was associated linearly whereas the other EAA were associated quadratically (Figure 1). For Ile, Leu, and Val (the branched-chain EAA), as MTP_MP increases, $\mathrm{p}[\mathrm{EAA}]$ concentration declines, reaching a nadir of 76.6, 82.9 , and $141.4 \mu M$ for Ile, Leu and Val, respectively, whereas $\mathrm{p}[\mathrm{Met}]$ and $\mathrm{p}[\mathrm{Phe}]$ reach their low points at 15.8 and $34.2 \mu M$, respectively. Table 8 also suggests that $\mathrm{p}[\mathrm{Thr}]$ is maintained between a minimum of 79.0 $\mu M$ and a maximum of $97.6 \mu M$. The $\mathrm{p}[\mathrm{Thr}]$ remains constant until the MTP_MP reaches $40 \%$, at which time it decreases at a gradually increasing rate. Plasma concentrations of Met from intact proteins and Phe decrease in parallel with Lys in spite of the quadratic nature of the best equations.

\section{Effect of Increasing Percentage of Microbial Protein}

Associated with each $1 \%$ increase in calculated MDP_MP was a 28-g decrease in MP flow to the duodenum $(P<0.001)$. In turn, this lead to a highly significant $(P<0.001)$ decrease in Argduo $(-1.19 \mathrm{~g})$, Hisduo $(-0.81 \mathrm{~g})$, Ileduo $(-1.28 \mathrm{~g})$, Leuduo $(2.78 \mathrm{~g})$, Lysduo ( $-1.55 \mathrm{~g})$, Metduo ( $-0.65 \mathrm{~g})$, Pheduo $(-1.55$ $\mathrm{g})$, Thrduo $(-1.18 \mathrm{~g})$, and Valduo $(-1.77 \mathrm{~g})$ for each percent increase in MDP_MP. Likewise, increasing MDP_MP was negatively associated with all $\mathrm{p}[\mathrm{EAA}]$ except $\mathrm{p}[\mathrm{Arg}]$ and $\mathrm{p}[\mathrm{Thr}]$. This association was linear for all EAA except for His, which was associated in a 


\begin{tabular}{|c|c|c|c|c|c|c|c|}
\hline First author & Year & Breed & Parity & Infusion & $\begin{array}{l}\text { Study } \\
\text { design }\end{array}$ & $\begin{array}{c}\text { Cows } \\
\text { sampled }\end{array}$ & Study objective was to determine: ${ }^{2}$ \\
\hline Awawdeh & 2007 & Holstein & 3 & & $4 \times 4 \mathrm{LS}$ & 4 & Lys digestibility in soybean meals \\
\hline Bach & 2000 & Holstein & 3 & & $4 \times 4 \mathrm{LS}$ & 4 & Effects of high and low quality of protein \\
\hline Bertrand & 1998 & Jersey & 2 & & $\mathrm{RCB}$ & 24 & RPMet and RPLys effects on production \\
\hline Berthiaume & 2001 & Holstein & 2 & & $\mathrm{RCB}$ & 15 & Degradability and digestibility of RPMet \\
\hline Berthiaume & 2006 & Holstein & 2 & & $3 \times 3 \mathrm{LS}$ & 6 & Effect of RPMet on splanchnic metabolism \\
\hline Blauwiekel & 1997 & Holstein & 3 & & $4 \times 4 \mathrm{LS}$ & 4 & Effect of gossypol RPLys \\
\hline Blouin & 2002 & Holstein & 2 & & $2 \times 2 \mathrm{LS}$ & 6 & MP effects on splanchnic flux \\
\hline Blum & 1999 & Mixed & 2 & & SB & 6 & Compare 2 RPMet supplements \\
\hline Borucki Castro & 2008 & Holstein & 3 & & $4 \times 4 \mathrm{LS}$ & 8 & Effect of soybean protein on N metabolism \\
\hline Boucher & 2007 & Holstein & 2 & & $4 \times 4 \mathrm{LS}$ & 4 & Effect of urea levels on microbial protein \\
\hline Bremmer & 1997 & Jersey & 2 & & $4 \times 4 \mathrm{LS}$ & 12 & Effect of RPAA and somatotropin \\
\hline Brito & 2008 & Holstein & 2 & & $\mathrm{SB}$ & 16 & Nitrogen metabolism in cows fed alfalfa \\
\hline \multirow[t]{2}{*}{ Broderick } & 1986 & Holstein & 3 & & SB & 6 & Expeller vs. solvent soybean meal \\
\hline & & & & & $4 \times 4 \mathrm{LS}$ & 20 & Effect of soybean meal types \\
\hline Broderick & 1993 & Holstein & 3 & & $4 \times 4 \mathrm{LS}$ & 12 & Urea vs. true protein \\
\hline Cabrita & 2011 & Holstein & 3 & & $8 \times 8 \mathrm{LS}$ & 18 & Effect of MP balance on performance \\
\hline Cant & 1993 & Holstein & 1 & Yes & $4 \times 4 \mathrm{LS}$ & 4 & Abomasal vs. ruminal casein infusion \\
\hline \multirow[t]{2}{*}{ Carvalho } & 2006 & Holstein & 2 & & $\mathrm{RCB}$ & 20 & Effect of palm kernel meal vs. distillers dried grains on performance \\
\hline & & & & & $\mathrm{RCB}$ & 18 & Effect of dried distillers grain on Lys metabolism \\
\hline Chan & 1997 & Holstein & 2 & & $4 \times 4 \mathrm{LS}$ & 4 & Fat and protein flow to duodenum \\
\hline Christen & 2010 & Holstein & 2 & & $4 \times 4 \mathrm{LS}$ & 12 & Distillers grain vs. other protein sources \\
\hline Christensen & 1994 & Holstein & 3 & & $4 \times 4 \mathrm{LS}$ & 4 & Effect of RPMet and RPLys on nutrient flows \\
\hline Christensen & 1996 & Holstein & 2 & & $4 \times 4 \mathrm{LS}$ & 4 & Fat and niacin on nutrient flows to duodenum \\
\hline \multirow{2}{*}{ Colin-Schoellen } & 1994 & Holstein & 2 & & $4 \times 4 \mathrm{LS}$ & 16 & RPMet and RPLys interaction with energy level \\
\hline & & & 2 & & $4 \times 4 \mathrm{LS}$ & 12 & RPMet and RPLys interaction with energy level \\
\hline Dalbach & 2011 & Holstein & 2 & & $\mathrm{RCB}$ & 16 & HMBi on nitrogen metabolism at 4 DIM \\
\hline \multirow{2}{*}{ Dalbach } & 2011 & & & & $\mathrm{RCB}$ & 16 & HMBi on nitrogen metabolism at 15 DIM \\
\hline & 2011 & & & & $\mathrm{RCB}$ & 16 & HMBi on nitrogen metabolism at 29 DIM \\
\hline Davidson & 2003 & Holstein & 2 & & $\mathrm{RCB}$ & 75 & RUP sources on nitrogen metabolism \\
\hline DeFrain & 2002 & Holstein & 3 & & $3 \times 3 \mathrm{LS}$ & 18 & Effect of corn steep liquor on nutrient metabolism \\
\hline Dinn & 1998 & Holstein & 3 & & $3 \times 3 \mathrm{LS}$ & 18 & RPMet and RPLys on nitrogen excretion \\
\hline Doepel & 2007 & Holstein & 3 & Yes & $2 \times 2 \mathrm{LS}$ & 8 & Glutamine effects on splanchnic metabolism \\
\hline Doepel & 2010 & Holstein & 1 & Yes & $4 \times 4 \mathrm{LS}$ & 4 & Essential AA on mammary metabolism \\
\hline Doepel & 2011 & Holstein & 1 & Yes & $3 \times 3 \mathrm{LS}$ & 6 & Arg effects on mammary metabolism \\
\hline Donkin & 1989 & Holstein & 3 & & SB & 4 & Effects of RPMet and RPLys on production \\
\hline Ellison Henson & 1997 & Holstein & 2 & & $3 \times 3 \mathrm{LS}$ & 12 & RUP supplements on nitrogen metabolism \\
\hline Erickson & 1992 & Holstein & 3 & & RCB & 40 & Effects of fat and nicotinic acid \\
\hline Guinard & $1994 \mathrm{a}$ & Holstein & 3 & Yes & $4 \times 4 \mathrm{LS}$ & 4 & Effects of casein infusion on mammary uptake \\
\hline Guinard & $1994 \mathrm{~b}$ & Holstein & 3 & Yes & $4 \times 4 \mathrm{LS}$ & 4 & Effects of Lys infusion on mammary uptake \\
\hline Guinard & 1995 & Holstein & 3 & Yes & $4 \times 4 \mathrm{LS}$ & 4 & Effects of Met infusion on mammary uptake \\
\hline Graulet & 2007 & Holstein & 3 & & $\mathrm{RCB}$ & 24 & Folic acid and $B_{12}$ supplementation on metabolism \\
\hline Hammon & 2008 & Holstein & 2 & & $3 \times 3 \mathrm{LS}$ & 3 & Fat supplementation on portal metabolism \\
\hline Hanigan & 2004 & Holstein & 2 & Yes & $4 \times 4 \mathrm{LS}$ & 4 & Casein infusion on nitrogen metabolism \\
\hline $\mathrm{Hu}$ & $2007 \mathrm{a}$ & Holstein & 3 & & $6 \times 6 \mathrm{LS}$ & 6 & Cation balance effects on metabolism \\
\hline $\mathrm{Hu}$ & $2007 \mathrm{~b}$ & Mixed & 3 & & $\mathrm{RCB}$ & 48 & Cation balance effects on metabolism \\
\hline Huhtanen & 2001 & Ayrshire & 3 & Yes & Inc. LS & 5 & His, Leu, and glucose infusion on metabolism \\
\hline Hurtaud & 1998 & Holstein & 2 & Yes & $4 \times 4 \mathrm{LS}$ & 4 & Effects of glucose infusion on protein yield \\
\hline Karunanandaa & 1994 & Jersey & 3 & & $4 \times 4 \mathrm{LS}$ & 8 & Effects of RPMet and RPLys on production \\
\hline King & 1990 & Holstein & 3 & & $3 \times 3 \mathrm{LS}$ & 6 & Protein sources on nitrogen metabolism \\
\hline Kleinschmit & 2006 & Holstein & 2 & & $3 \times 3 \mathrm{LS}$ & 12 & Evaluation of dried distillers grains on AA utilization \\
\hline Kleinschmit & 2007 & Holstein & 2 & & $4 \times 4 \mathrm{LS}$ & 8 & Evaluation of dried distillers grains plus soluble on AA utilization \\
\hline
\end{tabular}


Table 1 (Continued). Characteristics of studies included in the developmental database

\begin{tabular}{|c|c|c|c|c|c|c|c|}
\hline First author & Year & Breed & Parity & Infusion & $\begin{array}{l}\text { Study } \\
\text { design }^{1}\end{array}$ & $\begin{array}{l}\text { Cows } \\
\text { sampled }\end{array}$ & Study objective was to determine: ${ }^{2}$ \\
\hline Korhonen & 2000 & Ayrshire & 2 & Yes & $5 \times 5 \mathrm{LS}$ & 5 & Effect of level of His on milk protein production \\
\hline Korhonen & $2002 \mathrm{a}$ & Ayrshire & 3 & Yes & $5 \times 5 \mathrm{LS}$ & 5 & Effect of Ile, Leu, and Val on milk protein production \\
\hline Korhonen & $2002 \mathrm{~b}$ & Ayrshire & 3 & & $4 \times 4 \mathrm{LS}$ & 4 & Effect of protein source on milk protein production \\
\hline Kung, Jr. & 1984 & Holstein & 2 & & $\mathrm{RCB}$ & 94 & RUP effects on plasma AA \\
\hline LaCount & $1996 \mathrm{a}$ & Holstein & 3 & Yes & $4 \times 4 \mathrm{LS}$ & 4 & Effects of abomasal infusion of L-carnitine \\
\hline LaCount & $1996 \mathrm{~b}$ & Holstein & 3 & & $5 \times 5 \mathrm{LS}$ & 20 & Effects of feeding L-carnitine \\
\hline Lanham & 1992 & Holstein & 2 & & $\mathrm{RCB}$ & 40 & Cottonseed and niacin effects on milk protein \\
\hline \multirow[t]{3}{*}{ Larsen } & 2009 & Holstein & 2 & Yes & S plot & 12 & Glucose infusion on AA metabolism at 4 DIM \\
\hline & & Holstein & 2 & Yes & S plot & 12 & Glucose infusion on AA metabolism at 15 DIM \\
\hline & & Holstein & 2 & Yes & S plot & 12 & Glucose infusion on AA metabolism at 29 DIM \\
\hline Lee & $2012 \mathrm{a}$ & Holstein & 2 & & $\mathrm{RCB}$ & 24 & Effect of RPMet and RPLys on low MP diets \\
\hline Lee & $2012 b$ & Holstein & 2 & & $\mathrm{RCB}$ & 36 & Effect of RPMet, RPLys, and RPHis \\
\hline Lemosquet & 2009 & Holstein & 3 & Yes & $4 \times 4 \mathrm{LS}$ & 4 & Effect of AA infusion on glucose metabolism \\
\hline Mackle & 1999 & Holstein & 2 & Yes & $4 \times 4 \mathrm{LS}$ & 4 & Effect of casein and branched AA on milk protein \\
\hline Martineau & $2007 \mathrm{a}$ & Holstein & 3 & & $3 \times 3 \mathrm{LS}$ & 6 & Forage preservation on metabolism \\
\hline Martineau & $2007 \mathrm{~b}$ & Holstein & 1 & & $3 \times 3 \mathrm{LS}$ & 6 & Effects of ionophores on protein and glucose \\
\hline Miettinen & 1996 & Ayrshire & 3 & Yes & $4 \times 4 \mathrm{LS}$ & 4 & Infused VFA effects on milk yield \\
\hline Mjoun & $2010 \mathrm{a}$ & Holstein & 3 & & $\mathrm{RCB}$ & 36 & Dried distillers grain with solubles on AA use \\
\hline Mjoun & 2010b & Holstein & 2 & & RCB & 40 & Levels of distillers grain with solubles on AA use \\
\hline Moorby & 2002 & Holstein & 1 & & $\mathrm{RCB}$ & 40 & Level of concentrate effects on nitrogen balance \\
\hline Mulrooney & 2009 & Holstein & 2 & & $4 \times 4 \mathrm{LS}$ & 12 & Replace distiller with solubles with canola meal \\
\hline \multirow[t]{3}{*}{ Nagel } & 1992 & Holstein & 3 & & $\mathrm{RCB}$ & 22 & All 3 studies look at the effects of formic acid \\
\hline & & Holstein & 3 & & S plot & 22 & or formaldehyde treatment of alfalfa silage with \\
\hline & & Holstein & 3 & & $3 \times 3 \mathrm{LS}$ & 12 & and without fishmeal \\
\hline Nichols & 1998 & Holstein & 3 & & $4 \times 4 \mathrm{LS}$ & 12 & RPMet and RPLys with dried distillers grain and milk \\
\hline Noftsger & 2005 & Holstein & 2 & & $4 \times 4 \mathrm{LS}$ & 8 & Evaluation of 3 RPMet sources \\
\hline Oba & 2010 & Holstein & 3 & & $4 \times 4 \mathrm{LS}$ & 4 & Suitability of triticale distillers dried grain for dairy cows \\
\hline Overton & 1996 & Holstein & 2 & & $\mathrm{RCB}$ & 24 & Evaluation of RPMet product \\
\hline Overton & 1998 & Holstein & 3 & & S plot & 44 & Effect of carbohydrate on RPMet response \\
\hline \multirow[t]{2}{*}{ Palmquist } & 1982 & Jersey & 2 & & $4 \times 4 \mathrm{LS}$ & 4 & Both studies looked at AA availability of distillers \\
\hline & & Holstein & 2 & & $4 \times 4 \mathrm{LS}$ & 8 & dried grain and performance \\
\hline Piepenbrink & 1996 & Holstein & 3 & & $5 \times 5 \mathrm{LS}$ & 10 & Performance of cows fed low protein and RPMet \\
\hline Pisulewski & 1996 & Holstein & 3 & Yes & $5 \times 5 \mathrm{LS}$ & 5 & Response to increasing doses of infused Met \\
\hline Preynat & 2008 & Holstein & 3 & & $\mathrm{RCB}$ & 24 & Effect of folic acid and vitamin $B_{12}$ with RPMet \\
\hline Preynat & 2009 & Holstein & 3 & & $\mathrm{RCB}$ & 60 & Effect of RPMet and folic acid plus vitamin $B_{12}$ \\
\hline Raggio & 2004 & Holstein & 3 & & $3 \times 3 \mathrm{LS}$ & 6 & MP supply on splanchnic flux \\
\hline Rius & $2010 \mathrm{a}$ & Holstein & 1 & Yes & $2 \times 2 \mathrm{LS}$ & 6 & Infused starch and casein \\
\hline Rius & $2010 \mathrm{~b}$ & Holstein & 2 & & $\mathrm{RCB}$ & 40 & Milk protein response to starch and AA \\
\hline Rogers & 1987 & Holstein & 2 & & Inc. Blk & 36 & Milk protein response to RPMet and RPLys \\
\hline \multirow[t]{4}{*}{ Schwab } & $1992 \mathrm{a}$ & Holstein & 3 & Yes & $4 \times 4 \mathrm{LS}$ & 4 & Effect of casein, Met, or Lys at 30 DIM \\
\hline & $1992 \mathrm{a}$ & Holstein & 3 & Yes & $4 \times 4 \mathrm{LS}$ & 4 & Effect of casein, Met, or Lys at 70 DIM \\
\hline & $1992 \mathrm{a}$ & Holstein & 3 & Yes & $4 \times 4 \mathrm{LS}$ & 4 & Effect of casein, Met, or Lys at 133 DIM \\
\hline & $1992 \mathrm{a}$ & Holstein & 3 & Yes & $4 \times 4 \mathrm{LS}$ & 4 & Effect of casein, Met, or Lys at 170 DIM \\
\hline \multirow[t]{4}{*}{ Schwab } & $1992 b$ & Holstein & 3 & Yes & $4 \times 4 \mathrm{LS}$ & 4 & Effect of Met and Lys at 30 DIM \\
\hline & $1992 \mathrm{~b}$ & Holstein & 3 & Yes & $4 \times 4 \mathrm{LS}$ & 4 & Effect of Met and Lys at 70 DIM \\
\hline & $1992 b$ & Holstein & 3 & Yes & $4 \times 4 \mathrm{LS}$ & 4 & Effect of Met and Lys at 133 DIM \\
\hline & $1992 b$ & Holstein & 3 & Yes & $4 \times 4 \mathrm{LS}$ & 4 & Effect of Met and Lys at 270 DIM \\
\hline Seymour & 1990 & Holstein & 3 & Yes & Inc. Blk & 64 & Effect of casein or Met + Lys infusion on production \\
\hline St-Pierre & 2005 & Holstein & 2 & & $\mathrm{RCB}$ & 64 & Effect of HMB and HMBi on milk protein \\
\hline Tagari & 2007 & Holstein & 2 & & $2 \times 2 \mathrm{LS}$ & 8 & $\begin{array}{l}\text { Mammary uptake of AA of cows fed different starch } \\
\text { sources }\end{array}$ \\
\hline
\end{tabular}


quadratic manner (Table 9 and Figure 2). As can be seen in the figure, $\mathrm{p}[\mathrm{His}]$ is initially increased by increasing MCP percent, but then decreases at a slightly greater rate as the amount of $\mathrm{MCP} \_\mathrm{MP}$ continues to increase. Forcing the intercept through 0 (data not shown) reveals that $\mathrm{p}[\mathrm{Val}]$ decreases the most with a slope of -3.10 , whereas $\mathrm{p}[\mathrm{Phe}]$ decreases the least with a slope of 0.61 .

\section{Best Mixed Equations}

All included cow factors (BW, DIM, parity, milk yield, and MPY) and ration factors $\left[\mathrm{NE}_{\mathrm{l}} / \mathrm{kg}\right.$, NDF, NFC, ether extract, and ash (all \% of DM)] as well as MTP_MP and MDP_MP were added to regression equations that included EAAduo to determine if factors other than EAAduo influenced $\mathrm{p}[\mathrm{EAA}]$. Resultant equations are presented in Table 10. No cow factor except milk yield or MPY ever entered the equations. Ration factors entered all the associative equations (assuming MDP_MP and MTP_MP as ration factors) except for Met from protein and Arg, which were not improved beyond duodenal flow. The effects of NDF and NFC could both be expressed as having negative associations between duodenal flow of EAA and resultant blood levels. Energy concentration $\left(\mathrm{NE}_{\mathrm{l}} / \mathrm{kg}\right)$ of the diet had no effect on the association of EAAduo with $\mathrm{p}[\mathrm{EAA}]$. Milk production was a significant negative factor for association of duodenal Lys, Met from DL-Met, and Val with the respective p[EAA], whereas MPY was negatively associated with plasma Ile, Met from protein sources, and Phe. Adding the total significant terms decreased the RMSE for associations of $\mathrm{p}[\mathrm{EAA}]$ for His, Lys, Met from DL-Met, Thr, and Val. The RMSE for Met from protein and Phe remained unchanged.

\section{Evaluation of Associative Equations}

The regression equations derived from the developmental database were used to predict $\mathrm{p}[\mathrm{EAA}]$ using terms for EAAduo, EAA_MP, or all factors, including MTP_MP and MDP_MP. The predicted $\mathrm{p}[\mathrm{EAA}]$ were compared against observed values in the validation database with results presented in Table 11. In general, all associations provided reasonable estimates of $\mathrm{p}[\mathrm{EAA}]$ with Lys displaying the lowest $\operatorname{adj}^{2}$ and highest RMSE as \% of the mean and Met from DL-Met sources providing the highest $\operatorname{adj} R^{2}$ and lowest RMSE as $\%$ of mean. Quadratic equations generally reduced the RMSE slightly or not at all with resultant small changes in adjR ${ }^{2}$ and RMSE. Expressing duodenal protein flow as EAA_MP or adding ration or cow factors, or both, likewise had small effects both on RMSE or $\operatorname{adj} \mathrm{R}^{2}$ for predictions of $\mathrm{p}[\mathrm{EAA}]$ for the validation data- 
Table 2. Characteristics of studies included in the validation database

\begin{tabular}{|c|c|c|c|c|c|c|c|c|}
\hline First author & Year & $\begin{array}{l}\text { Blood } \\
\text { source }\end{array}$ & Breed & Parity & Infusion & $\operatorname{Design}^{1}$ & $\begin{array}{l}\text { Cows } \\
\text { sampled }\end{array}$ & Study objective was to determine: \\
\hline Abu-Ghazaleh & 2001 & Serum & Holstein & 3 & & $4 \times 4 \mathrm{LS}$ & 12 & Effects of replacing soybean meal with fish meal \\
\hline Broderick & 1974 & Plasma & Mixed & 3 & & $5 \times 5 \mathrm{LS}$ & 5 & If AA build up in plasma when requirement is met \\
\hline Casper 1 & 1987 & Serum & Holstein & 2 & & $\mathrm{RCB}$ & 23 & Effects of whole soybean and soybean meal with Met \\
\hline Casper 2 & 1988 & Serum & Holstein & 2 & & $\mathrm{RCB}$ & 28 & Effects of added Met on high barley diets \\
\hline Casper 3 & 1990 & Serum & Holstein & 2 & & $\mathrm{RCB}$ & 28 & Effects of added NFC on high fat rations \\
\hline Choi & 2002 & Plasma & Ayrshire & 2 & & $5 \times 5 \mathrm{LS}$ & 5 & Compare $\mathrm{N}$ flow in cows fed differing a-fraction proteins ${ }^{2}$ \\
\hline Choung & 1993 & Plasma & Holstein & 3 & Yes & $4 \times 4 \mathrm{LS}$ & 4 & Effects of abomasal infusions of casein \\
\hline Clark & 1977 & Plasma & Holstein & 2 & Yes & $4 \times 4 \mathrm{LS}$ & 4 & Effects of high quality protein and glucose \\
\hline Coomer & 1993 & Plasma & Holstein & 3 & & $\mathrm{RCB}$ & 24 & Effects of added NFC for cows fed high fat rations \\
\hline Drackley & 1986 & Serum & Holstein & 2 & & $\mathrm{RCB}$ & 30 & $\begin{array}{l}\text { The AA flow to mammary gland of cows fed soybean or } \\
\text { sunflower protein }\end{array}$ \\
\hline Fathi Nasri & 2007 & Plasma & Holstein & 3 & & $\mathrm{RCB}$ & 18 & $\begin{array}{l}\text { Performance of cows fed soybean meal, raw, or roasted whole } \\
\text { soybeans }\end{array}$ \\
\hline Garnsworthy & 2008 & Plasma & Holstein & 3 & & $\mathrm{RCB}$ & 32 & Effect of high or low Leu on ovarian function \\
\hline Hadrova & 2012 & Plasma & Holstein & 2 & Yes & $\mathrm{SB}$ & 3 & If His could be a limiting AA \\
\hline Hadsell & 1988 & Serum & Holstein & 2 & & $\mathrm{RCB}$ & 30 & The value of chickpeas as protein source for cows \\
\hline Haque & 2013 & Plasma & Holstein & 3 & Yes & $4 \times 4 \mathrm{LS}$ & 4 & Effects of imbalance of AA \\
\hline Harouna & 1997 & Serum & Holstein & 2 & & $\mathrm{RCB}$ & 30 & The optimum dietary fat and RUP for lactating cows \\
\hline Krizova & 2008 & Plasma & Holstein & 2 & & $\mathrm{SB}$ & 4 & If Leu could be a limiting AA \\
\hline Krober & 2000 & Plasma & Brown Swiss & 3 & & $4 \times 4 \mathrm{LS}$ & 4 & Effects of Lys, Met, or Lys + Met on milk protein yield \\
\hline Liu & 2000 & Serum & Holstein & 3 & & $\mathrm{RCB}$ & 40 & Value of corn distillers grain to a blend of other proteins \\
\hline Lapierre & 2009 & Plasma & Holstein & 3 & Yes & SB & 6 & If a deficiency of Lys affects protein metabolism \\
\hline Maiga & 1997 & Serum & Holstein & 2 & & $\mathrm{RCB}$ & 40 & Evaluate diets for milk protein yield when feeding high fat \\
\hline Miettinen & 1997 & Plasma & Ayrshire & 3 & Yes & $4 \times 4 \mathrm{LS}$ & 4 & $\begin{array}{l}\text { Effects of casein on production of cows fed } \\
\text { silages that differed in fermentation characteristics }\end{array}$ \\
\hline Pacheco-Rios & 1998 & Plasma & Holstein & 2 & & $2 \times 2 \mathrm{LS}$ & 4 & Effect of feed restriction on AA metabolism \\
\hline Papas & 1984 & Plasma & Holstein & 3 & & $\mathrm{RCB}$ & 30 & Plasma Met levels to determine effectiveness of RPMet \\
\hline Piepenbrink & 1998 & Serum & Holstein & 2 & & $5 \times 5 \mathrm{LS}$ & 10 & Best system to predict milk and protein yield \\
\hline Plaizier & 2001 & Plasma & Holstein & 3 & Yes & $4 \times 4 \mathrm{LS}$ & 4 & Effects of glutamine on milk protein yield \\
\hline Raggio & 2006 & Plasma & Holstein & 3 & Yes & $3 \times 4 \mathrm{YS}$ & 3 & $\begin{array}{l}\text { Effect of casein and propionic acid on kinetics of glucose and } \\
\text { Leu }\end{array}$ \\
\hline Richter & 2010 & Plasma & Holstein & 3 & Yes & $4 \times 4 \mathrm{LS}$ & 4 & Possibility of Leu as third limiting AA \\
\hline Schei 1 & 2007 & Plasma & Norway Red & 2 & Yes & $4 \times 4 \mathrm{LS}$ & 8 & $\begin{array}{l}\text { Effects of starch, glucose, or AA infused ruminally or } \\
\text { abomasally in early lactation }\end{array}$ \\
\hline Schei 2 & 2007 & Plasma & Norway Red & 2 & Yes & $4 \times 4 \mathrm{LS}$ & 8 & $\begin{array}{l}\text { Effects of starch, glucose, or AA infused ruminally or } \\
\text { abomasally in late lactation }\end{array}$ \\
\hline Spires & 1975 & Plasma & Holstein & 2 & Yes & SB & 5 & $\mathrm{~N}$ utilization when given casein infusion \\
\hline Yang & 1986 & Serum & Holstein & 2 & & $\mathrm{RCB}$ & 24 & Other limiting AA when rumen RPMet was fed \\
\hline
\end{tabular}

${ }^{1} \mathrm{LS}=$ Latin square; $\mathrm{RCB}=$ randomized complete block; $\mathrm{SB}=$ switch-back; YS = Youden square.

a-fraction $=$ NPN and some true protein that is assumed to be instantly degradable (NRC, 2001) 
Table 3. Description of cow and ration factors for developmental and validation databases

\begin{tabular}{|c|c|c|c|c|c|c|c|c|}
\hline Item & \multicolumn{4}{|c|}{ Developmental database } & \multicolumn{4}{|c|}{ Validation database } \\
\hline \multicolumn{9}{|l|}{ Cow-associated factors } \\
\hline DIM & 125 & 61 & 4 & 321 & 113 & 54 & 54 & 260 \\
\hline $\mathrm{BW}, \mathrm{kg}$ & 603.1 & 59.9 & 410 & 756 & 595 & 50.3 & 498 & 733 \\
\hline Milk, kg/d & 30.6 & 6.4 & 14.8 & 47.7 & 30.3 & 6.5 & 13.9 & 40.8 \\
\hline Milk fat $\%$ & 3.73 & 0.5 & 2.37 & 5.47 & 3.74 & 0.7 & 2.65 & 5.6 \\
\hline DMI, $\mathrm{kg} / \mathrm{d}$ & 20.3 & 3.4 & 8.5 & 29.4 & 20.1 & 3.5 & 12.3 & 28.4 \\
\hline \multicolumn{9}{|l|}{ Ration-associated factors } \\
\hline $\mathrm{NE}_{1},{ }^{1}$ Mcal $/ \mathrm{kg}$ & 1.56 & 0.11 & 1.17 & 1.77 & 1.58 & 0.08 & 1.37 & 1.78 \\
\hline $\mathrm{CP}, \%$ of $\mathrm{DM}$ & 16.4 & 1.9 & 9.3 & 24.7 & 16.2 & 2.1 & 9.0 & 22.4 \\
\hline $\mathrm{ADF}, \%$ of $\mathrm{DM}$ & 19.9 & 4.6 & 13.0 & 65.1 & 19.1 & 3.2 & 14.9 & 30.4 \\
\hline $\mathrm{NDF}, \%$ of DM & 33.6 & 5.0 & 22.0 & 53.3 & 32.9 & 5.5 & 24.6 & 52.4 \\
\hline NFC, $\%$ of DM & 38.4 & 5.5 & 22.8 & 50.5 & 40.0 & 6.5 & 9.1 & 50.2 \\
\hline RUP, g/d & 1,183 & 111 & 300 & 3,330 & 1,161 & 395 & 470 & 2,370 \\
\hline MDP_MP ${ }^{2}$ & 67.7 & 8.2 & 34.4 & 84.2 & 67.4 & 9.0 & 40.5 & 84.9 \\
\hline
\end{tabular}

${ }^{1}$ Calculated according to NRC (2001).

${ }^{2} \mathrm{MDP} \_\mathrm{MP}=$ microbial digestible $\mathrm{CP}$ as a percent of total MP.

Table 4. Descriptive statistics for duodenal flow and plasma concentration of essential AA in developmental and validation databases

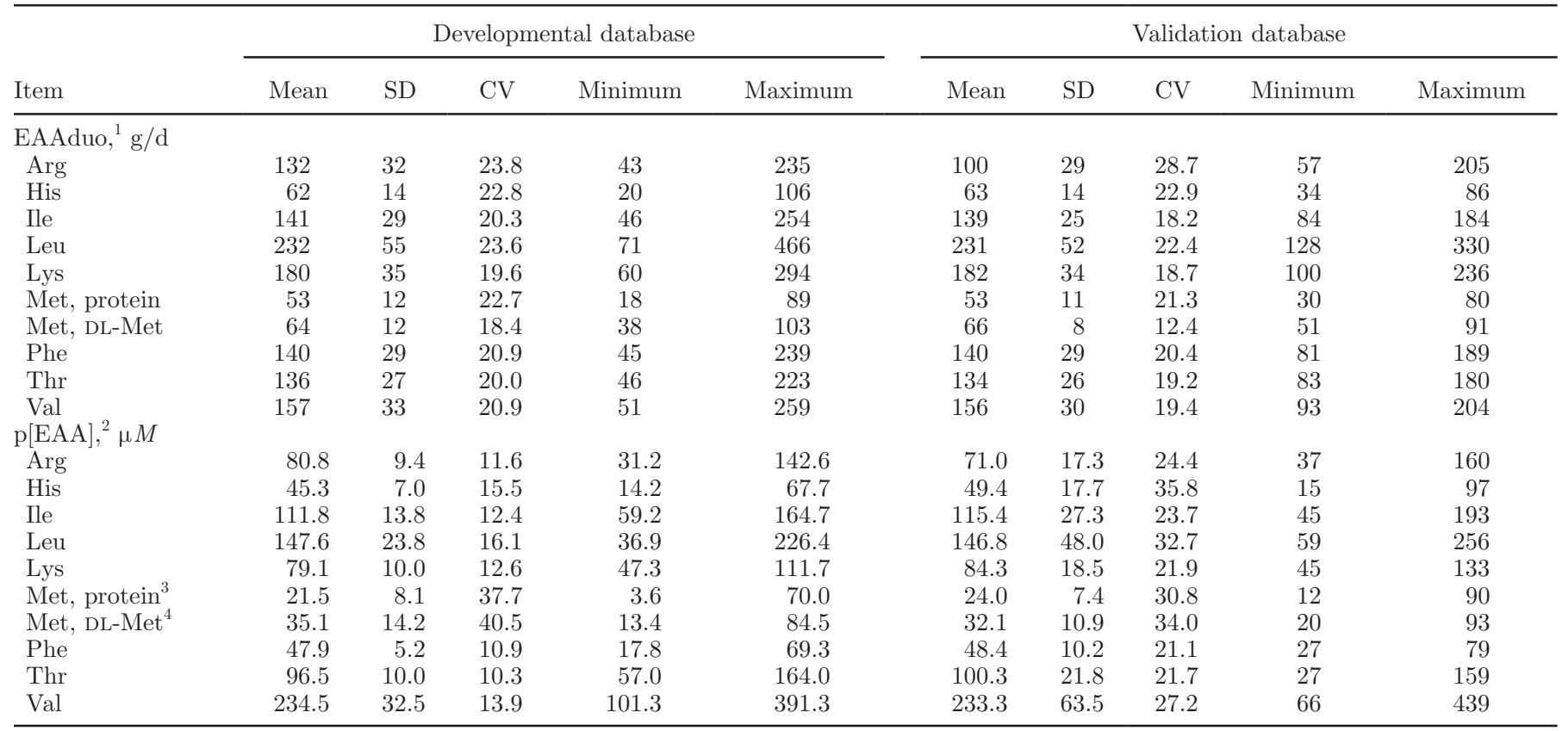

${ }^{1}$ EAAduo $=$ estimated daily duodenal flow of essential AA.

${ }^{2} \mathrm{p}[\mathrm{EAA}]=$ plasma (and serum except for Arg) concentration of essential AA.

${ }^{3}$ Met, protein $=$ Met derived from intact dietary protein.

${ }^{4}$ Met, DL-Met $=$ Met derived from DL-Met sources. 
Table 5. Relationships between plasma AA concentration $(\mu M)$ and duodenal AA flow (AAduo, g/d) for the developmental database

\begin{tabular}{|c|c|c|c|c|c|c|c|c|}
\hline $\mathrm{p}[\mathrm{AA}]$ & Model type & $\mathrm{N}$ & $\operatorname{adj}^{2}$ & $\operatorname{Mean}^{1}$ & $\mathrm{RMSE}^{2}$ & $\begin{array}{l}\text { RMSE, } \\
\% \text { mean }^{3}\end{array}$ & $\begin{array}{l}\text { Intercept, } \\
\% \text { mean }\end{array}$ & Best equation \\
\hline $\operatorname{Arg}$ & $\begin{array}{l}\text { Linear } \\
\text { Quadratic }\end{array}$ & 366 & $\begin{array}{l}0.904 \\
\mathrm{NS}^{4}\end{array}$ & 80.8 & 9.0 & 11.1 & 62.7 & $50.64+(0.220 \times$ Argduo $)$ \\
\hline His & $\begin{array}{l}\text { Linear } \\
\text { Quadratic }\end{array}$ & 403 & $\begin{array}{l}0.800 \\
\text { NS }\end{array}$ & 45.3 & 7.6 & 16.8 & 46.4 & $21.02+(0.392 \times$ Hisduo $)$ \\
\hline Ile & $\begin{array}{l}\text { Linear } \\
\text { Quadratic }\end{array}$ & 419 & $\begin{array}{l}0.769 \\
0.783\end{array}$ & $\begin{array}{l}111.8 \\
111.8\end{array}$ & $\begin{array}{l}14.2 \\
13.8\end{array}$ & $\begin{array}{l}12.7 \\
12.3\end{array}$ & 48.4 & $\begin{array}{l}54.05+(0.414 \times \text { Ileduo }) \\
-8.28+(1.283 \times \text { Ileduo })-\left(0.003 \times \text { Ileduosq }^{5}\right)\end{array}$ \\
\hline Leu & $\begin{array}{l}\text { Linear } \\
\text { Quadratic }\end{array}$ & 417 & $\begin{array}{l}0.811 \\
\text { NS }\end{array}$ & 147.6 & 24.4 & 16.5 & 25.6 & $37.79+(0.483 \times$ Leuduo $)$ \\
\hline Lys & $\begin{array}{l}\text { Linear } \\
\text { Quadratic }\end{array}$ & 418 & $\begin{array}{l}0.824 \\
0.829\end{array}$ & $\begin{array}{l}79.1 \\
79.1\end{array}$ & $\begin{array}{l}9.8 \\
9.7\end{array}$ & $\begin{array}{l}12.4 \\
12.2\end{array}$ & 38.3 & $\begin{array}{l}30.32+(0.268 \times \text { Lysduo }) \\
-9.42+(0.730 \times \text { Lysduo })-(0.001 \times \text { Lysduosqr })\end{array}$ \\
\hline Met, protein ${ }^{6}$ & $\begin{array}{l}\text { Linear } \\
\text { Quadratic }\end{array}$ & 320 & $\begin{array}{l}0.877 \\
0.885\end{array}$ & $\begin{array}{l}21.3 \\
21.3\end{array}$ & $\begin{array}{l}3.3 \\
3.2\end{array}$ & $\begin{array}{l}15.5 \\
15.0\end{array}$ & 49.5 & $\begin{array}{l}10.54+(0.21 \times \text { Metduo }) \\
-2.74+(0.72 \times \text { Metduo })-(0.005 \times \text { Metduosqr })\end{array}$ \\
\hline Met, DL-Met ${ }^{7}$ & $\begin{array}{l}\text { Linear } \\
\text { Quadratic }\end{array}$ & 98 & $\begin{array}{l}0.904 \\
\mathrm{NS}\end{array}$ & 35.2 & 5.6 & 15.9 & 2.0 & $0.69+(0.53 \times$ Metduo $)$ \\
\hline Phe & $\begin{array}{l}\text { Linear } \\
\text { Quadratic }\end{array}$ & 414 & $\begin{array}{l}0.858 \\
\text { NS }\end{array}$ & 48.0 & 5.4 & 11.3 & 55.6 & $26.58+(0.153 \times$ Pheduo $)$ \\
\hline Thr & $\begin{array}{l}\text { Linear } \\
\text { Quadratic }\end{array}$ & 410 & $\begin{array}{l}0.906 \\
0.912\end{array}$ & $\begin{array}{l}96.5 \\
96.5\end{array}$ & $\begin{array}{l}11.0 \\
10.6\end{array}$ & $\begin{array}{l}11.4 \\
11.0\end{array}$ & $\begin{array}{r}57.1 \\
-7.2\end{array}$ & $\begin{array}{l}55.06+(0.300 \times \text { Thrduo }) \\
-6.98+(1.252 \times \text { Thrduo })-(0.003 \times \text { Thrduosqr })\end{array}$ \\
\hline Val & $\begin{array}{l}\text { Linear } \\
\text { Quadratic }\end{array}$ & 420 & $\begin{array}{l}0.844 \\
0.851\end{array}$ & $\begin{array}{l}234.5 \\
234.5\end{array}$ & $\begin{array}{l}31.1 \\
30.4\end{array}$ & $\begin{array}{l}13.3 \\
13.0\end{array}$ & 15.6 & $\begin{array}{l}36.49+(1.264 \times \text { Valduo }) \\
-101.82+(3.060 \times \text { Valduo })-(0.006 \times \text { Valduosqr })\end{array}$ \\
\hline
\end{tabular}

${ }^{1}$ Mean $=$ mean plasma AA concentration $(\mu M)$

${ }^{2} \mathrm{RMSE}=$ root mean square error.

¿ $\quad{ }^{3} \mathrm{RMSE}, \%$ mean $=$ root mean square error as a percent of the mean for linear equations only.

${ }^{4} \mathrm{NS}=$ quadratic term not significant.

$\stackrel{5}{5}$ EAAduosqr $=$ EAAduo $\times$ EAAduo.

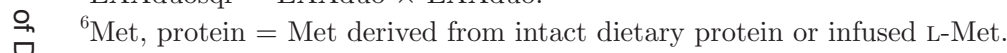

$\stackrel{{ }^{7}}{\equiv}$ Met, DL-Met $=$ Met was partially supplied from DL-Met, either as rumen protected-Met or infused. 
Table 6. Relationships between plasma AA concentration $(\mu M)$ and duodenal AA flow as percent of MP (AA_MP) for the developmental database

\begin{tabular}{|c|c|c|c|c|c|c|c|c|}
\hline $\mathrm{p}[\mathrm{AA}]$ & Model type & $\mathrm{N}$ & $\operatorname{adj}^{2}$ & Mean $^{1}$ & $\mathrm{RMSE}^{2}$ & $\begin{array}{l}\text { RMSE, } \\
\% \text { mean }^{3}\end{array}$ & $\begin{array}{c}\text { Intercept, } \\
\% \text { mean }\end{array}$ & Best equation \\
\hline \multirow[t]{2}{*}{$\operatorname{Arg}$} & Linear & 366 & 0.908 & 80.8 & 8.8 & 10.9 & 23.3 & $18.85+(12.64 \times$ Arg_MP $)$ \\
\hline & Quadratic & & 0.913 & 80.8 & 8.6 & 10.6 & & $223.31-(71.12 \times$ Arg_MP $)+\left(8.52 \times\right.$ Arg_MPsqr $\left.{ }^{4}\right)$ \\
\hline \multirow[t]{2}{*}{ His } & Linear & 403 & 0.804 & 45.3 & 7.6 & 16.7 & 3.7 & $1.66+(19.22 \times$ His_MP $)$ \\
\hline & Quadratic & & $\mathrm{NS}^{5}$ & & & & & \\
\hline \multirow[t]{2}{*}{ Ile } & Linear & & NS & & & & & \\
\hline & Quadratic & & NS & & & & & \\
\hline \multirow[t]{2}{*}{ Leu } & Linear & 417 & 0.770 & 147.6 & 27.0 & 18.3 & 55.6 & $82.00+(8.02 \times$ Leu_MP $)$ \\
\hline & Quadratic & & NS & & & & & \\
\hline \multirow[t]{2}{*}{ Lys } & Linear & 418 & 0.812 & 79.1 & 10.1 & 12.8 & 14.7 & $11.63+(10.14 \times$ Lys_MP $)$ \\
\hline & Quadratic & & 0.834 & 79.1 & 9.5 & 12.1 & & $127.56-(27.78 \times$ Lys_MP $)+(3.06 \times$ Lys_MPsqr $)$ \\
\hline \multirow[t]{2}{*}{ Met, protein ${ }^{6}$} & Linear & 320 & 0.874 & 21.3 & 3.4 & 16.0 & & $-10.44+(16.76 \times$ Met_MP $)$ \\
\hline & Quadratic & & NS & & & & & \\
\hline \multirow[t]{2}{*}{ Met, DL-Met ${ }^{7}$} & Linear & 98 & 0.921 & 35.3 & 5.0 & 14.2 & -28.3 & $-9.99+(18.08 \times$ Met_MP $)$ \\
\hline & Quadratic & & 0.922 & 35.3 & 5.0 & 14.2 & & $-62.03+(55.69 \times$ Met_MP $)-(6.46 \times$ Met_MPsqr $)$ \\
\hline Phe & $\begin{array}{l}\text { Linear } \\
\text { Ouadratic }\end{array}$ & 414 & $\begin{array}{l}0.842 \\
\text { NS }\end{array}$ & 47.9 & 5.7 & & 18.1 & $8.67+(7.63 \times$ Phe_MP $)$ \\
\hline \multirow[t]{2}{*}{ Thr } & Linear & & 0.907 & 96.5 & 10.9 & 11.3 & -15.7 & $-15.15+(22.16 \times$ Thr_MP $)$ \\
\hline & Quadratic & & NS & & & & & \\
\hline \multirow[t]{2}{*}{ Val } & Linear & 420 & 0.791 & 234.5 & 35.9 & 15.3 & -13.5 & $-31.70+(46.44 \times$ Val_MP $)$ \\
\hline & Quadratic & 420 & 0.797 & 234.5 & 35.4 & 15.1 & 399.3 & $936.19-(287.95 \times$ Val_MP $)+(28.82 \times$ Val_MPsqr $)$ \\
\hline
\end{tabular}

${ }^{1}$ Mean $=$ mean plasma AA concentration $(\mu M)$.

${ }^{2} \mathrm{RMSE}=$ root mean square error

${ }^{3} \mathrm{RMSE}, \%$ mean $=$ root mean square error as a percent of the mean.

${ }^{4} \mathrm{EAA} \_\mathrm{MPsqr}=\mathrm{EAA} \_\mathrm{MP} \times \mathrm{EAA} \_\mathrm{MP}$.

${ }^{5} \mathrm{NS}=$ no significant equation or quadratic term not significant

${ }^{6}$ Met, protein $=$ Met derived from intact dietary protein or infused L-Met.

${ }^{7}$ Met, DL-Met $=$ Met was partially supplied from DL-Met, either as rumen protected-Met or infused. 
Table 7. Correlations between MP supply, duodenal flow (g/d), and plasma concentration $(\mu M)$ of individual essential AA

\begin{tabular}{|c|c|c|c|c|}
\hline \multirow[b]{2}{*}{$\mathrm{AA}$} & \multicolumn{2}{|c|}{ Duodenal flow } & \multicolumn{2}{|c|}{$\begin{array}{c}\text { Plasma } \\
\text { concentration }\end{array}$} \\
\hline & $\mathrm{R}^{2}$ & $P$-value & $\mathrm{R}^{2}$ & $P$-value \\
\hline $\operatorname{Arg}$ & 0.832 & $<0.001$ & 0.922 & 0.006 \\
\hline His & 0.826 & $<0.001$ & 0.787 & $<0.001$ \\
\hline Ile & 0.902 & $<0.001$ & 0.763 & $<0.001$ \\
\hline Leu & 0.853 & $<0.001$ & 0.808 & $<0.001$ \\
\hline Lys & 0.838 & $<0.001$ & 0.772 & 0.001 \\
\hline Met, protein ${ }^{1}$ & 0.877 & $<0.001$ & 0.804 & 0.001 \\
\hline Met, DL-Met ${ }^{2}$ & 0.340 & $<0.001$ & 0.087 & 0.002 \\
\hline Phe & 0.945 & $<0.001$ & 0.840 & $<0.001$ \\
\hline Thr & 0.966 & $<0.001$ & 0.900 & $<0.001$ \\
\hline Val & 0.958 & $<0.001$ & 0.824 & $<0.001$ \\
\hline
\end{tabular}

${ }^{1}$ Met, protein $=$ Met derived from intact dietary protein.

${ }^{2}$ Met, DL-Met $=$ Met derived from DL-Met sources.

base. In summary, the most efficient overall estimate of $\mathrm{p}[\mathrm{EAA}]$ remained the equation with estimated EAAduo with a linear relationship.

\section{Effects of Increasing Duodenal Flow of Individual AA}

Preliminary regression equations indicated that EAA composition of the MP may have an effect on the $\mathrm{p}[\mathrm{EAA}]$ of individual AA. However, the high correlation between all EAAduo and individual EAAduo (i.e., high correlation between MP and AA flow) made clear interpretation of any such relationships impossible. For this reason it was decided to compare the effects of an increase in a single EAAduo on the corresponding $\mathrm{p}[\mathrm{EAA}]$ as well as other AA. The effects of adding Met, Lys, or His singly, as well as the effect of adding Met + Lys were contrasted to the effects of infused casein, an instance where all AA are increased.

When only Met was added either by infusion or as RPMet (all as DL-Met; mean $=19 \mathrm{~g} / \mathrm{d}$ ), Met was the only EAA whose predicted flow was altered $(P<0.001$; Table 12). This was accompanied by a significant increase in $\mathrm{p}[\mathrm{Met}]$ as well as a decrease $(P \leq 0.03)$ in plasma concentrations of all EAA except Arg and Lys. Although feed intake and milk yield were unchanged, milk true protein \% (MTPPct) and MPY tended to increase $(P=0.07$ for each $)$ by Met addition. When Lys was supplemented (mean $=30 \mathrm{~g} / \mathrm{d}$ ), Lysduo was the only EAA estimated to increase $(P=0.003)$. This addition resulted in higher $\mathrm{p}[\mathrm{Lys}]$ as well as lower $\mathrm{p}$ [His] $(P=0.004)$ and a tendency for $\mathrm{p}[\mathrm{Phe}]$ to be reduced also $(P=0.06$; Table 12$)$. No production variables were affected by Lys supplementation in this database. Adding His $(10 \mathrm{~g} / \mathrm{d})$ resulted in predicted higher $(P<0.01)$ Hisduo and higher $(P=0.01) \mathrm{p}[$ His $]$. No other $\mathrm{p}[\mathrm{EAA}]$ were affected, but increased His supply resulted in both greater milk production $(P<0.001)$ and $\operatorname{MPY}(P=$ $0.02)$, with a tendency $(P=0.06)$ to increase DMI (Table 12).

Given the results above, it was expected that adding Met + Lys (estimated difference in duodenal flow was $+18 \mathrm{~g}$ of Lys and $+7 \mathrm{~g}$ of Met) should increase both Lysduo and Metduo, as well as increase plasma Lys and Met, and should result in decreases in other plasma EAA, particularly His. However, except for greater plasma concentration of Lys and Met, no other p[EAA] changes were detected. The addition of both Lys and Met resulted in a greater milk true protein percent, without a difference in MPY (Table 12). When casein was infused into the duodenum, the predicted duodenal flows of all EAA were increased $(P<0.001)$ and all plasma AA increased $(P \leq 0.02)$ with the exception of Arg. This resulted in greater $(P \leq 0.04) \mathrm{MPY}$ and MTPPct.

\section{DISCUSSION}

When interpreting these data, it is necessary to keep in mind that duodenal flows of EAA are predicted values, although model predicted values have been shown to be reasonably accurate over a wide range of diet types (Pacheco et al., 2012). It is acknowledged that variation in ingredients and ingredient quality as well as errors in prediction of amount and EAA composition of microbial protein may well lead to errors in prediction of EAAduo in individual studies. The effect of these potential variations on the development of equations should have been reduced by the inclusion of study as a random term in all models (St-Pierre, 2001). Also, because of the nature of the experimental data, many of the reported studies are Latin square designs that may introduce transient or short-term changes in $\mathrm{p}[\mathrm{EAA}]$, or through mobilization of body protein, no changes in $\mathrm{p}[\mathrm{EAA}]$ at all. These changes, or lack of changes, may not be seen with longer experimental times. It becomes a matter of conjecture as to when dietary changes become stable. However, without these Latin square studies, the data available become severely limiting.

Given these limitations, little evidence was observed from this study that $\mathrm{p}[\mathrm{EAA}]$ displayed any break point that would be indicative of fulfilling an EAA requirement as $\mathrm{p}[\mathrm{EAA}]$ were mainly linearly related to their respective EAAduo. Although the RMSE was lower for quadratic equations, the adj $R^{2}$ was only very slightly enhanced $(<0.02)$ and RMSE as a percent of the mean only slightly decreased $(<1.0 \%)$ as presented in Table 5 . Even when quadratic effects were significant, curvilinear change was introduced only at high levels of duodenal flow (Figure 3a). If more restrictive elimination of samples had been employed (e.g., $\pm 2.5 \mathrm{SD}$ ), 
Table 8. Relationships between plasma AA concentration $(\mu M)$ and percent of MP excreted as MPY (MTP_MP)

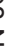

\begin{tabular}{|c|c|c|c|c|c|c|}
\hline $\mathrm{p}[\mathrm{AA}]$ & $\operatorname{adj} R^{2}$ & Mean $^{1}$ & Model & $\mathrm{RMSE}^{2}$ & $\begin{array}{l}\text { RMSE, } \\
\% \text { mean }^{3}\end{array}$ & Equation \\
\hline$\overline{\operatorname{Arg}}$ & $\begin{array}{l}\mathrm{NS}^{4} \\
\mathrm{NS}\end{array}$ & 80.8 & $\begin{array}{l}\text { Linear } \\
\text { Quadratic }\end{array}$ & & & \\
\hline His & NS & 45.3 & Linear & & & \\
\hline \multirow[t]{2}{*}{ Ile } & $\begin{array}{l}\text { NS } \\
0.757\end{array}$ & 111.8 & $\begin{array}{l}\text { Quadratic } \\
\text { Linear }\end{array}$ & 14.5 & 13.0 & $167.90-\left(1.31 \times \mathrm{MTP} \_\mathrm{MP}^{5}\right)$ \\
\hline & 0.763 & & Quadratic & 14.3 & 12.8 & $208.10-(2.99 \times$ MTP_MP $)+\left(0.017 \times\right.$ MTP_MPsqr $\left.{ }^{6}\right)$ \\
\hline \multirow[t]{2}{*}{ Leu } & 0.806 & 147.6 & Linear & 24.8 & 16.8 & $260.41-(2.60 \times$ MTP_MP \\
\hline & 0.821 & & Quadratic & 23.9 & 16.2 & $380.62-(7.56 \times$ MTP_MP $)+(0.048 \times$ MTP_MPsqr $)$ \\
\hline Lys & $\begin{array}{l}0.765 \\
\text { NS }\end{array}$ & 79.1 & $\begin{array}{l}\text { Linear } \\
\text { Quadratic }\end{array}$ & 11.3 & 14.3 & $91.80-(0.31 \times$ MTP_MP $)$ \\
\hline \multirow{2}{*}{ Met, protein ${ }^{7}$} & 0.873 & 21.3 & Linear & 3.4 & 16.0 & $32.80-(0.27 \times$ MTP_MP $)$ \\
\hline & 0.877 & & Quadratic & 3.4 & 15.8 & $42.18-\left(0.65 \times \mathrm{MTP} \_\mathrm{MP}\right)+\left(0.004 \times \mathrm{MTP} \_\mathrm{MPsqr}\right)$ \\
\hline Met, DL-Met ${ }^{8}$ & $\begin{array}{l}\text { NS } \\
\text { NS }\end{array}$ & 35.2 & $\begin{array}{l}\text { Linear } \\
\text { Quadratic }\end{array}$ & & & \\
\hline \multirow[t]{2}{*}{ Phe } & 0.852 & 47.9 & Linear & 5.5 & 11.5 & $68.17-(0.47 \times$ MTP_MP $)$ \\
\hline & 0.854 & & Quadratic & 5.5 & 11.5 & $82.79-(1.08 \times$ MTP_MP $)+(0.006 \times$ MTP_MPsqr $)$ \\
\hline \multirow{2}{*}{ Thr } & 0.901 & 96.5 & Linear & 11.2 & 11.6 & $118.96-(0.55 \times$ MTP_MP $)$ \\
\hline & 0.905 & & Quadratic & 11 & 11.4 & $79.00+(1.09 \times$ MTP_MP $)-(0.016 \times$ MTP_MPsqr $)$ \\
\hline \multirow[t]{2}{*}{ Val } & 0.813 & 234.5 & Linear & 33.9 & 14.5 & $391.10-\left(3.66 \times \mathrm{MTP} \_\mathrm{MP}\right)$ \\
\hline & 0.822 & & Quadratic & 33.1 & 14.1 & $532.10-(9.52 \times$ MTP_MP $)+(0.058 \times$ MTP_MPsqr $)$ \\
\hline
\end{tabular}

${ }^{1}$ Mean $=$ mean plasma AA concentration $(\mu M)$.

${ }^{2} \mathrm{RMSE}=$ root mean square error.

${ }^{3} \mathrm{RMSE}, \%$ mean $=$ root mean square error as a percent of the mean.

${ }^{4} \mathrm{NS}=$ no significant equation or quadratic term not significant.

${ }^{5} \mathrm{MTP} \_\mathrm{MP}=$ milk protein yield (MPY) as a percent of MP.

${ }^{6} \mathrm{MTP} \_\mathrm{MPsqr}=\mathrm{MTP} \_\mathrm{MP} \times \mathrm{MTP} \_\mathrm{MP}$.

${ }^{7}$ Met, protein $=$ Met derived from intact dietary protein.

${ }^{8}$ Met, DL-Met $=$ Met derived from DL-Met sources. 
Table 9. Relationships between plasma AA concentration $(\mu M)$ and microbial digestible $\mathrm{CP}$ as a percent of MP $\left.\left(\mathrm{MDP} \_\mathrm{MP}\right)^{1}\right)$

\begin{tabular}{|c|c|c|c|c|c|c|}
\hline $\mathrm{p}[\mathrm{AA}]$ & $\operatorname{adj} R^{2}$ & Mean $^{1}$ & Model & $\mathrm{RMSE}^{2}$ & $\underset{\text { mean }^{3}}{\mathrm{RMSE}, \%}$ & Equation \\
\hline $\operatorname{Arg}$ & $\begin{array}{l}\text { NS } \\
\text { NS }\end{array}$ & 80.5 & $\begin{array}{l}\text { Linear } \\
\text { Quadratic }\end{array}$ & & & \\
\hline His & $\begin{array}{l}0.793 \\
0.801\end{array}$ & $\begin{array}{l}45.3 \\
45.3\end{array}$ & $\begin{array}{l}\text { Linear } \\
\text { Quadratic }\end{array}$ & $\begin{array}{l}7.8 \\
7.6\end{array}$ & 17.2 & $\begin{array}{l}73.37-\left(0.41 \times \mathrm{MDP} \_\mathrm{MP}^{5}\right) \\
-7.06+\left(2.19 \times \mathrm{MDP} \_\mathrm{MP}\right)-\left(0.021 \times \mathrm{MDP} \_\mathrm{MPsqr} \mathrm{r}^{6}\right)\end{array}$ \\
\hline Ile & $\begin{array}{l}0.754 \\
\text { NS }\end{array}$ & 111.8 & $\begin{array}{l}\text { Linear } \\
\text { Quadratic }\end{array}$ & 14.6 & 13.1 & $188.83-\left(1.11 \times \mathrm{MDP} \_\mathrm{MP}\right)$ \\
\hline Leu & $\begin{array}{l}0.831 \\
\text { NS }\end{array}$ & 147.6 & $\begin{array}{l}\text { Linear } \\
\text { Quadratic }\end{array}$ & 23.2 & 15.7 & $344.07-(2.87 \times$ MDP_MP $)$ \\
\hline $\mathrm{p}[$ Lys $] \mu M$ & $\begin{array}{l}0.766 \\
\text { NS }\end{array}$ & 79.1 & $\begin{array}{l}\text { Linear } \\
\text { Quadratic }\end{array}$ & 11.2 & 14.1 & $94.50-(0.23 \times$ MDP_MP $)$ \\
\hline $\mathrm{p}[$ Met $] \mu M$, Protein $^{7}$ & $\begin{array}{l}0.863 \\
\text { NS }\end{array}$ & 21.4 & $\begin{array}{l}\text { Linear } \\
\text { Quadratic }\end{array}$ & 3.6 & 16.8 & $34.17-(0.18 \times$ MDP_MP $)$ \\
\hline $\mathrm{p}[$ Met $] \mu M$, DL-Met ${ }^{8}$ & $\begin{array}{l}\text { NS } \\
\text { NS }\end{array}$ & 34.1 & $\begin{array}{l}\text { Linear } \\
\text { Quadratic }\end{array}$ & & & \\
\hline $\mathrm{p}[\mathrm{Phe}] \mu M$ & $\begin{array}{l}0.843 \\
\mathrm{NS}\end{array}$ & 47.9 & $\begin{array}{l}\text { Linear } \\
\text { Quadratic }\end{array}$ & 5.7 & 11.9 & $75.74-\left(0.41 \times \mathrm{MDP} \_\mathrm{MP}\right)$ \\
\hline $\mathrm{p}[\mathrm{Thr}] \mu M$ & $\begin{array}{l}\text { NS } \\
\text { NS }\end{array}$ & 96.5 & $\begin{array}{l}\text { Linear } \\
\text { Quadratic }\end{array}$ & & & \\
\hline $\mathrm{p}[$ Val $] \mu M$ & $\begin{array}{l}0.824 \\
\text { NS }\end{array}$ & 234.5 & $\begin{array}{l}\text { Linear } \\
\text { Quadratic }\end{array}$ & 32.9 & 14.0 & $480.16-(3.61 \times$ MDP_MP $)$ \\
\hline
\end{tabular}

${ }^{1}$ Mean = mean plasma AA concentration $(\mu M)$.

${ }^{2} \mathrm{RMSE}=$ root mean square error.

${ }^{3} \mathrm{RMSE}, \%$ Mean $=$ root mean square error as a percent of the mean

c $\quad{ }^{4} \mathrm{NS}=$ no significant equation or quadratic term not significant.

$\stackrel{{ }_{3}}{\mathrm{~g}} \mathrm{MDP} \_\mathrm{MP}=$ microbial digestible protein as a percent of MP.

$\stackrel{6}{6} \mathrm{MDP} \_\mathrm{MPsqr}=\mathrm{MDP} \_\mathrm{MP} \times \mathrm{MDP} \_\mathrm{MP}$.

${ }^{7}$ Met, protein $=$ Met derived from intact dietary protein.

$\stackrel{8}{\Sigma}$ Met, DL $=$ Met derived from DL-Met sources. 


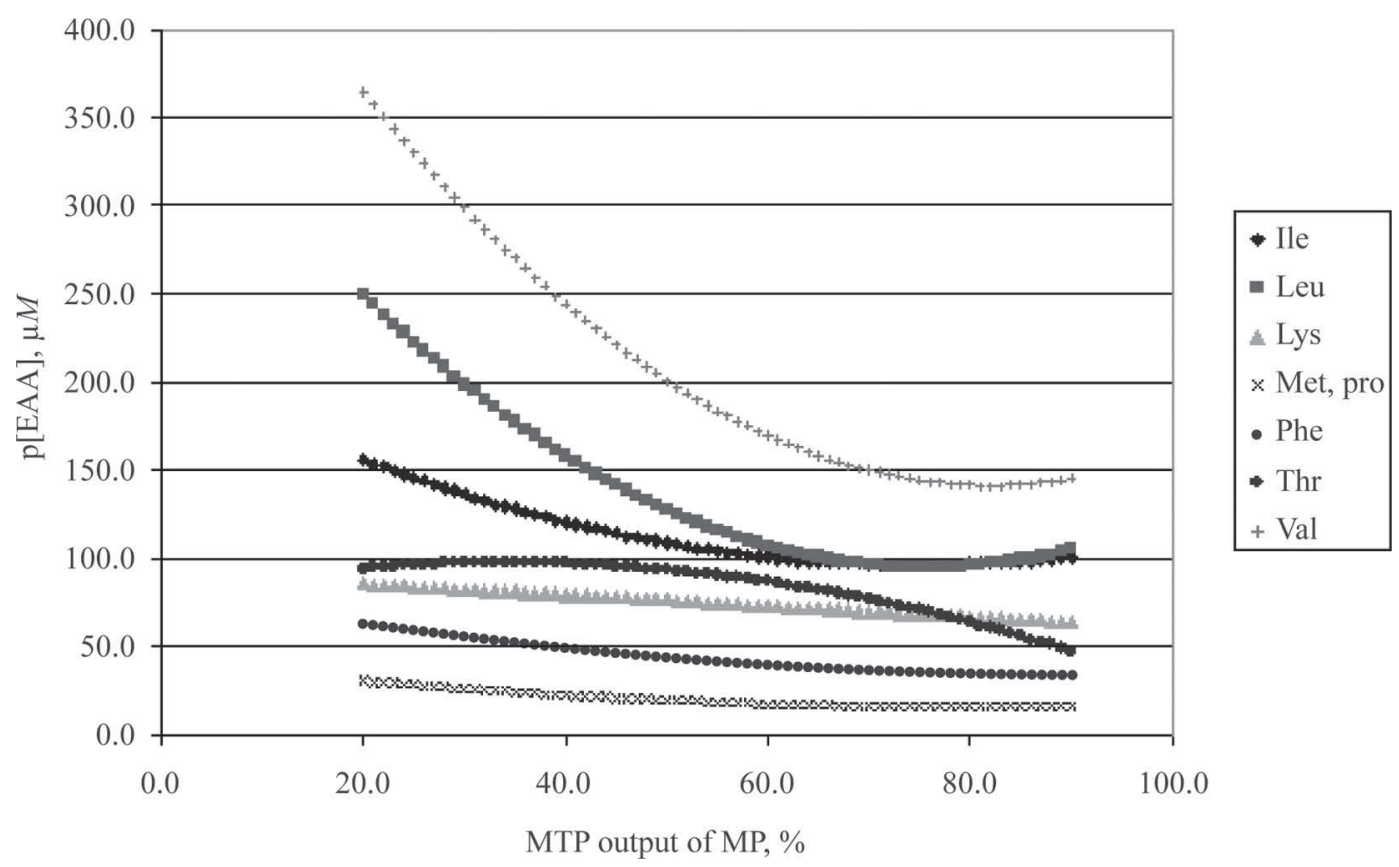

Figure 1. Regression plot of association of percent milk true protein output as a percent of MP (MTP_MP) with plasma concentration of $\mathrm{AA}(\mathrm{p}[\mathrm{EAA}], \mu M)$ over the range of observed data.

it is doubtful that curvilinear effects would have been detected. The plateau of p[Ile] occurs at $128.9 \mu \mathrm{M}$ with a Ileduo of $204 \mathrm{~g}$ (Figure 3a), whereas p[Thr] peaks at $126.2 \mu M$ with $199 \mathrm{~g}$ of Thrduo, and $\mathrm{p}[\mathrm{Val}]$ at 288.1 $\mu M$ with $250 \mathrm{~g}$ of Valduo. The other EAA appear linear over the range of duodenal flow, including Lys, which has a significant quadratic term. Similarly, $\mathrm{p}$ [Met] from protein sources plateaued at $23 \mu \mathrm{M}$ with $70 \mathrm{~g}$ of Metduo (Figure $3 \mathrm{~b}$ ). This plateau appears to mean little as plasma levels from DL-Met sources were considerably

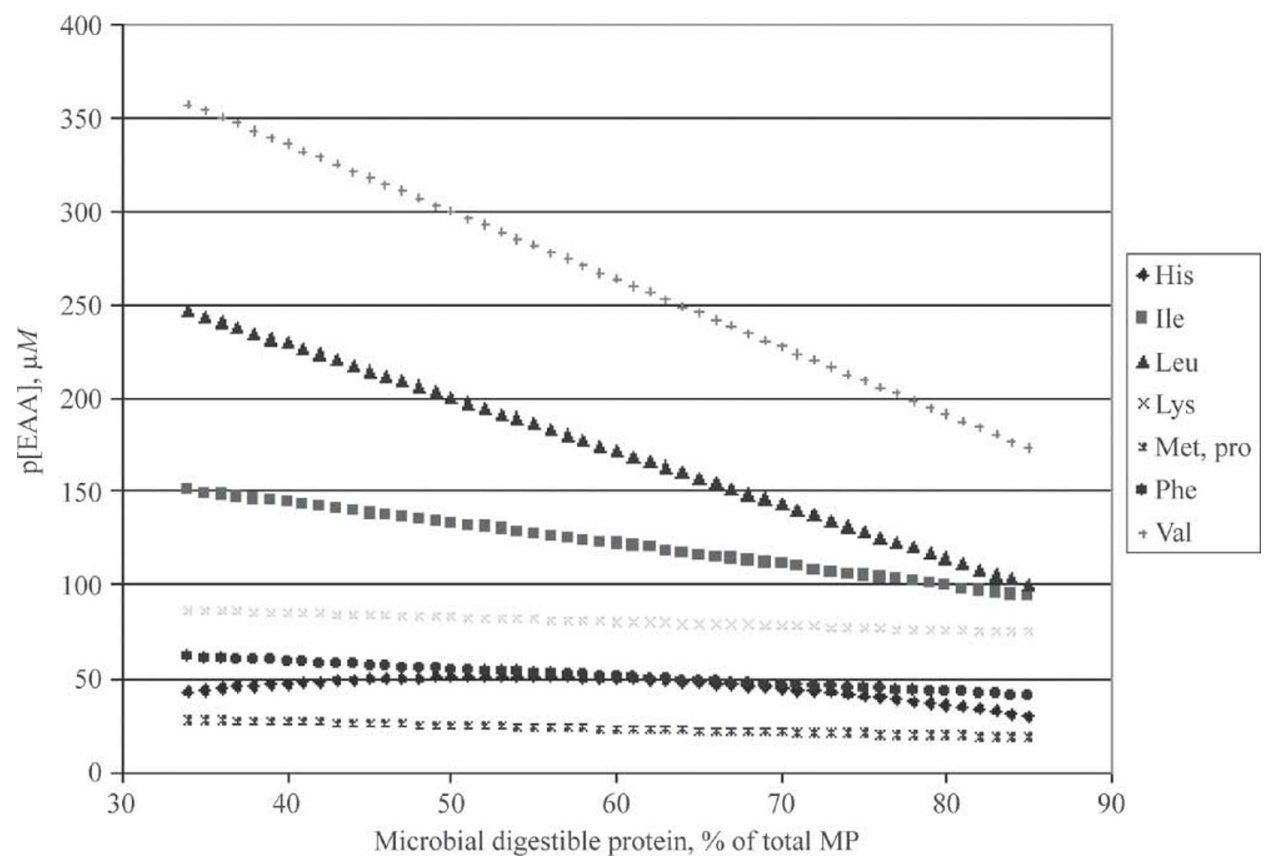

Figure 2. Regression plot of association between increasing microbial digestible protein as a percent of total MP and plasma concentration of $\mathrm{AA}(\mathrm{p}[\mathrm{EAA}], \mu M)$ over the range of observed data. 
Table 10. Mixed term equations relating plasma concentrations of EAA ( $\mu M$ ) to duodenal flow of AA (AAduo) with cow or ration factors, or both, with highest adjR ${ }^{2}$ and lowest root mean square error (RMSE) for developmental database

\begin{tabular}{|c|c|c|c|c|c|}
\hline $\mathrm{p}[\mathrm{AA}], \mu M$ & $\operatorname{adj} R^{2}$ & Mean $^{1}$ & RMSE & $\begin{array}{l}\text { RMSE, } \\
\% \text { mean }^{2}\end{array}$ & Equation \\
\hline Arg & \multicolumn{4}{|c|}{ No improvement possible } & \\
\hline His & 0.815 & 45.3 & 7.5 & 16.6 & $-38.83+(0.31 \times$ Hisduo $)+\left(2.51 \times\right.$ MDP_MP $\left.{ }^{3}\right)-\left(0.02 \times\right.$ MDP_MPsqr $\left.{ }^{4}\right)-\left(1.36 \times \mathrm{EE}^{5}\right)$ \\
\hline Ile & 0.802 & 111.8 & 13 & 11.6 & $\begin{array}{l}164.82+(1.24 \times \text { Ileduo })-\left(0.003 \times \text { Ileduosqr }^{6}\right)-\left(1.73 \times \mathrm{NDF}^{7}\right)-\left(1.92 \times \mathrm{NFC}^{8}\right)+\left(4.35 \times \text { ash }^{9}\right) \\
-(0.48 \times \text { MDP_MP })-\left(37.92 \times \mathrm{MPY}^{10}\right)\end{array}$ \\
\hline Leu & 0.837 & 147.6 & 23.1 & 15.6 & $227.27+(0.28 \times$ Leuduo $)-(2.09 \times$ MDP_MP $)$ \\
\hline Lys & 0.858 & 79.1 & 8.8 & 11.1 & $\begin{array}{l}-95.60+(01.24 \times \text { Lysduo })-\left(0.002 \times \text { Lysduosqr }^{2}\right)-(0.27 \times \text { MDP_MP })-\left(2.05 \times \text { Milk }^{11}\right)+(3.36 \\
\times \text { MTP_MP }\end{array}$ \\
\hline Met, protein ${ }^{14}$ & 0.89 & 21.4 & 3.2 & 15 & $3.51+(1.02 \times$ Metduo $)-(0.006 \times$ Metduosqr $)-(1.90 \times \mathrm{MPY})$ \\
\hline Met, DL-Met ${ }^{15}$ & 0.928 & 34.8 & 4.7 & 13.5 & $-74.74+(0.52 \times$ Metduo $)-(0.84 \times$ Milk $)+(1.48 \times \mathrm{NDF})+(1.33 \times \mathrm{NFC})$ \\
\hline Phe & 0.859 & 47.9 & 5.4 & 11.3 & $56.58+(0.15 \times$ Pheduo $)-(0.22 \times$ MDP_MP $)-(15.44 \times$ MPY $)$ \\
\hline Thr & 0.917 & 96.5 & 10.3 & 10.7 & $\begin{array}{l}-75.40+(1.16 \times \text { Thrduo })-(0.003 \times \text { Thrduosqr })+(0.57 \times \text { NFC })+(1.73 \times \text { MTP_MP })-(0.015 \\
\times \text { MTP_MPsqr })\end{array}$ \\
\hline Val & 0.864 & 234.5 & 29.3 & 12.5 & $370.27+(3.41 \times$ Valduo $)-(0.007 \times$ Valduosqr $)-(4.07 \times \mathrm{NDF})-(3.95 \times \mathrm{NFC})-(3.22 \times$ milk $)$ \\
\hline
\end{tabular}

${ }^{1}$ Mean $=$ mean plasma AA concentration $(\mu M)$.

${ }^{2} \mathrm{RMSE}, \%$ Mean $=$ root mean square error as a percent of the mean.

${ }^{3} \mathrm{MDP} \_\mathrm{MP}=$ microbial digestible protein as a percent of MP $(\mathrm{g} / \mathrm{g})$.

${ }^{4} \mathrm{MDP} \_\mathrm{MPsqr}=\mathrm{MDP} \_\mathrm{MP} \times \mathrm{MDP} \_\mathrm{MP}$.

${ }^{5}$ Ether extract, $\%$ of DM.

${ }^{6}$ EAAduosqr $=$ EAAduo $\times$ EAAduo

${ }^{7} \mathrm{NDF}=\mathrm{NDF}, \%$ of DM

${ }^{8} \mathrm{NFC}=\mathrm{NFC}, \%$ of DM.

${ }^{9} \mathrm{Ash}=$ ash, $\%$ of DM

${ }^{10} \mathrm{MPY}=$ milk true protein yield, $\mathrm{kg} / \mathrm{d}$

Milk = milk yield, $\mathrm{kg} / \mathrm{d}$.

일 $\quad{ }^{12} \mathrm{MTP} \_\mathrm{MP}=$ milk true protein yield as a $\%$ of MP $(\mathrm{g} / \mathrm{g})$.

${ }^{13} \mathrm{MTP} \_\mathrm{MPsqr}=\mathrm{MTP} \_\mathrm{MP} \times \mathrm{MTP} \_\mathrm{MP}$.

₹. ${ }^{14}$ Met, protein $=$ Met derived from intact dietary protein.

D $\quad{ }^{15}$ Met, DL $=$ Met derived from DL-Met sources. 


\begin{tabular}{|c|c|c|c|c|c|c|c|c|c|c|c|}
\hline \multirow[b]{2}{*}{$\mathrm{p}[\mathrm{AA}], \mu M$} & \multirow[b]{2}{*}{ Model } & \multirow[b]{2}{*}{$\begin{array}{c}\text { Concentration, } \\
\mu M\end{array}$} & \multirow[b]{2}{*}{$\mathrm{SE}$} & \multirow[b]{2}{*}{$\operatorname{adjR}^{2}$} & \multirow[b]{2}{*}{ RMSE } & \multirow{2}{*}{$\begin{array}{l}\text { RMSE, \% } \\
\text { observed } \\
\text { mean }\end{array}$} & \multirow[b]{2}{*}{ Intercept } & \multirow[b]{2}{*}{ Slope } & \multicolumn{3}{|c|}{ Error resolution, \% } \\
\hline & & & & & & & & & Mean & Regression & Random \\
\hline \multirow{4}{*}{$\overline{\operatorname{Arg}}$} & Observed & 71.0 & 17.3 & & & & & & & & \\
\hline & $\begin{array}{l}\text { Duo Linear } \\
\text { Duo Quadratic }\end{array}$ & 75.7 & 5.8 & $\begin{array}{l}0.830 \\
\mathrm{NS}^{3}\end{array}$ & 7.2 & 10.1 & -36.32 & 1.48 & 6.3 & 9.5 & 84.2 \\
\hline & AA_MP Linear ${ }^{4}$ & 76.9 & 4.7 & 0.808 & 8.8 & 12.4 & 97.90 & -0.29 & 10.1 & 5.0 & 84.9 \\
\hline & $\begin{array}{l}\text { AA_MP Quadratic } \\
\text { Mixed term }\end{array}$ & 77.6 & 2.7 & $\begin{array}{l}0.808 \\
\text { NS }\end{array}$ & 8.8 & & 125.37 & -0.64 & 12.5 & 1.9 & 85.6 \\
\hline \multirow[t]{4}{*}{ His } & Observed & 49.4 & 17.7 & & & & & & & & \\
\hline & $\begin{array}{l}\text { Duo Linear } \\
\text { Duo Quadratic }\end{array}$ & 45.6 & 5.9 & $\begin{array}{l}0.845 \\
\text { NS }\end{array}$ & 8.1 & 16.4 & -22.46 & 0.16 & 5.6 & 2.8 & 91.6 \\
\hline & $\begin{array}{l}\text { AA_MP Linear } \\
\text { AA_MP Quadratic }\end{array}$ & 46.2 & 4.8 & $\begin{array}{l}0.803 \\
\text { NS }\end{array}$ & 9.1 & 18.4 & -21.17 & 1.57 & 4.1 & 8.4 & 87.5 \\
\hline & Mixed term & 51.8 & 6.0 & 0.829 & 8.7 & 17.6 & 3.50 & 0.56 & 2.2 & 1.0 & 96.8 \\
\hline \multirow[t]{6}{*}{ Ile } & Observed & 115.4 & 27.3 & & & & & & & & \\
\hline & Duo Linear & 111.9 & 10.5 & 0.820 & 13.7 & 11.9 & 0.12 & 1.07 & 2.9 & 0.4 & 96.7 \\
\hline & Duo Quadratic & 109.6 & 12.3 & 0.816 & 13.8 & 11.9 & 23.70 & 0.86 & 4.7 & 1.5 & 93.8 \\
\hline & AA_MP Linear & & & NS & & & & & & & \\
\hline & AA_MP Quadratic & & & NS & & & & & & & \\
\hline & Mixed term & 107.2 & 17.0 & 0.810 & 14.0 & 12.1 & 61.82 & 0.53 & 9.3 & 4.5 & 86.2 \\
\hline \multirow{4}{*}{ Leu } & Observed & 146.8 & 48.1 & & & & & & & & \\
\hline & $\begin{array}{l}\text { Duo Linear } \\
\text { Duo Quadratic }\end{array}$ & 148.4 & 25.1 & $\begin{array}{l}0.856 \\
\text { NS }\end{array}$ & 20.9 & 14.2 & -22.95 & 1.15 & 0.2 & 6.9 & 92.9 \\
\hline & $\begin{array}{l}\text { AA_MP Linear } \\
\text { AA_MP Quadratic }\end{array}$ & 150.2 & 4.7 & $\begin{array}{l}0.829 \\
\text { NS }\end{array}$ & 23.0 & 15.7 & -77.20 & 1.50 & 0.5 & 7.0 & 92.5 \\
\hline & Mixed term & 150.8 & 30.7 & 0.837 & 20.5 & 14.0 & 28.14 & 0.79 & 1.6 & 2.8 & 95.6 \\
\hline \multirow[t]{6}{*}{ Lys } & Observed & 84.3 & 18.7 & & & & & & & & \\
\hline & Duo Linear & 79.3 & 9.1 & 0.796 & 9.8 & 11.6 & -1.01 & 1.09 & 6.1 & 10.6 & 83.3 \\
\hline & Duo Quadratic & 89.0 & 13.2 & 0.790 & 9.95 & 11.7 & 18.93 & 0.76 & 4.8 & 22.1 & 73.2 \\
\hline & AA MP Linear & 80.5 & 5.8 & 0.672 & 12.2 & 14.5 & 65.61 & 0.25 & 3.4 & 10.5 & 86.1 \\
\hline & AA_MP Quadratic & 81.0 & 8.4 & 0.671 & 12.2 & 14.5 & 72.69 & 0.16 & 2.3 & 18.1 & 79.6 \\
\hline & Mixed term & 64.4 & 4.6 & 0.711 & 11.5 & 13.6 & 7.88 & 1.22 & 54.6 & 0.0 & 45.4 \\
\hline \multirow[t]{6}{*}{ Met-protein } & Observed & 24.0 & 7.4 & & & & & & & & \\
\hline & Duo Linear & 24.8 & 5.2 & 0.918 & 2.54 & 10.6 & 9.60 & 0.59 & 1.0 & 0.21 & 78.0 \\
\hline & Duo Quadratic & 21.3 & 2.9 & 0.915 & 2.59 & 10.8 & 6.47 & 0.53 & 12.3 & 2.2 & 85.5 \\
\hline & AA MP Linear & 22.7 & 3.9 & 0.908 & 2.70 & 11.3 & 12.28 & 0.53 & 2.5 & 13.9 & 83.6 \\
\hline & AA_MP Quadratic & 22.9 & 4.3 & 0.911 & 2.65 & 11.0 & 11.66 & 0.55 & 1.9 & 17.0 & 81.1 \\
\hline & Mixed term & 19.2 & 3.8 & 0.915 & 2.58 & 10.8 & 12.52 & 0.61 & 69.7 & $\begin{array}{r}1.0 \\
1.9\end{array}$ & 28.4 \\
\hline \multirow[t]{5}{*}{ Met-DL } & Observed & 32.1 & 18.8 & & & & & & & & \\
\hline & $\begin{array}{l}\text { Duo Linear } \\
\text { Duo Quadratic }\end{array}$ & 35.1 & 3.0 & $\begin{array}{l}0.827 \\
\text { NS }\end{array}$ & 5.8 & 17.9 & -16.66 & 1.31 & 6.9 & 7.0 & 86.1 \\
\hline & AA_MP Linear & 32.7 & 3.4 & 0.913 & 4.2 & 13.1 & -41.98 & 2.21 & 0.4 & 5.2 & 94.4 \\
\hline & AA_MP Quadratic & 33.2 & 4.8 & 0.915 & 4.2 & 13.1 & -22.42 & 1.58 & 1.4 & 0.4 & 98.2 \\
\hline & Mixed term & 34.5 & 5.2 & 0.817 & 5.8 & 17.9 & -12.91 & 1.25 & 6.0 & 0.0 & 94 \\
\hline \multirow[t]{4}{*}{ Phe } & Observed & 48.4 & 10.2 & & & & & & & & \\
\hline & $\begin{array}{l}\text { Duo Linear } \\
\text { Duo Quadratic }\end{array}$ & 47.6 & 4.3 & 0.885 & 4.01 & 8.3 & 45.68 & 0.06 & 0.6 & 7.4 & 92.0 \\
\hline & AA_MP Linear & 48.2 & 3.0 & $\begin{array}{l}\text { NS } \\
0.886 \\
\text { NS }\end{array}$ & 4.02 & 8.4 & 45.90 & 0.06 & 0.0 & 2.1 & 98.0 \\
\hline & Mixed term & 48.9 & 4.2 & 0.885 & 4.04 & 8.3 & 42.15 & 0.14 & 0.3 & 4.9 & 94.8 \\
\hline
\end{tabular}




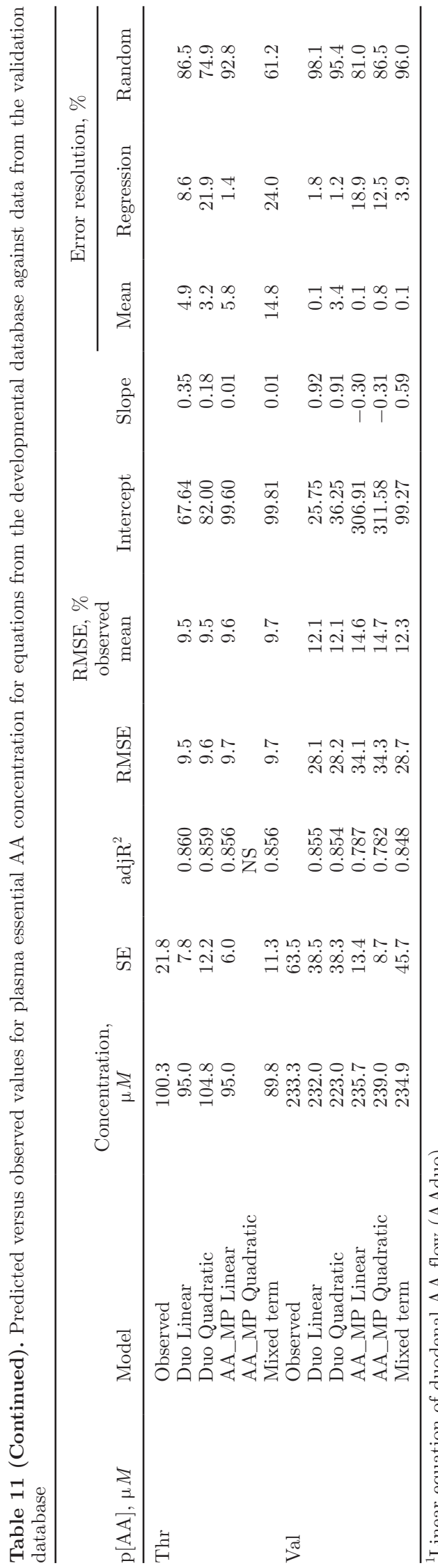

higher. Interestingly, almost all the studies that were eliminated were either infusion or high doses of RPMet, suggesting that it is possible to obtain unphysiological plasma concentrations under these experimental conditions. At least most the high concentrations were probably achieved through accumulation of D-Met in the plasma, as D-Met has a half-life more than 6 times longer than L-Met (Lapierre et al., 2012a). Additionally, even after these studies were removed, upper limit to the concentration of $\mathrm{p}$ [Met] from DL-Met sources, at least under the conditions of the studies included in the database, appeared to be quite high. Overall, as EAAduo increased, the $\mathrm{p}[\mathrm{EAA}]$ concentration of corresponding EAA increased. However, a biological minimum limit of $\mathrm{p}[\mathrm{EAA}]$ does seem to exist that the cow maintains under restricted supply as indicated by the intercept term in the linear equations.

Circulating AA concentrations are the result of EAAduo, digestibility, and EAA utilization. Removal of EAA increases with increased supply, either through increased hepatic removal (Raggio et al., 2004), peripheral tissue (as muscle) removal (Dalbach et al., 2011), and removal by the mammary gland (Raggio et al., 2006). Additionally, removal of EAA from plasma may also be the result of a greater use of plasma EAA for non-EAA production for milk protein in both dairy cattle (Lapierre et al., 2012b) and swine (Trottier et al., 1997). So, even expressing supply relative to milk true protein output, thereby expressing a relative excess over the major protein output, did not improve the prediction of $\mathrm{p}[\mathrm{EAA}]$ (Table 8 ). All of these observations tend to suggest a rather tight control of $\mathrm{p}[\mathrm{EAA}]$, increasing steadily with increased amount of EAA reaching the duodenum.

The decreasing $\mathrm{p}[\mathrm{EAA}]$ with increasing percentage of MDP may suggest that the EAA content of microbial protein is not as well balanced as has been suggested (Patton, 2009). Alternatively, it may be that the AA content of microbial protein or an $80 \%$ digestibility for AA of microbial origin as used in the AminoCow model (Evonik Industries, 2012) may not accurately reflect the true availability of these AA. However, the fact that MDP_MP was found to be negatively associated with $\mathrm{p}[\mathrm{EAA}]$ in several mixed equations suggests that increasing MDP_MP does indeed lead to lower p[EAA]. Even with this potential deficiency, the finding of a curvilinear relationship of $\mathrm{p}[\mathrm{His}]$ to increasing $\mathrm{MCP}$ does suggest that the His may become more deeply deficient than other EAA, but only if MCP represents $>70 \%$ of total MP. Also interesting is the relatively constant level of $\mathrm{p}$ [Lys] as MCP increases, which seems to confirm the proposed relatively high content of Lys in MCP (Clark et al., 1992). 
Table 12. Effect of addition of individual EAA to duodenal flow on production variables and plasma EAA concentration

\begin{tabular}{|c|c|c|c|c|c|c|c|c|c|c|c|c|c|c|c|c|c|c|c|c|}
\hline \multirow[b]{2}{*}{ Variable } & \multicolumn{4}{|c|}{$\operatorname{Met}(\mathrm{n}=34)$} & \multicolumn{4}{|c|}{ Lys $(\mathrm{n}=11)$} & \multicolumn{4}{|c|}{ His $(\mathrm{n}=8)$} & \multicolumn{4}{|c|}{ Met + Lys $(\mathrm{n}=41)$} & \multicolumn{4}{|c|}{ Casein $(\mathrm{n}=21)$} \\
\hline & Control & Treated & SE & $P$ & Control & Treated & SE & $P$ & Control & Treated & $\mathrm{SE}$ & $P$ & Control & Treated & $\mathrm{SE}$ & $P$ & Control & Treated & $\mathrm{SE}$ & $P$ \\
\hline \multicolumn{21}{|l|}{ Production } \\
\hline DMI, kg/d & 19.8 & 20 & 0.7 & 0.39 & 19.2 & 19.2 & 1.2 & 0.88 & 17.9 & 18.2 & 1.4 & 0.06 & 23.5 & 23.5 & 1.4 & 0.77 & 17.4 & 17.6 & 1.0 & 0.60 \\
\hline Milk, kg/d & 31.6 & 31.5 & 1.4 & 0.76 & 28.6 & 29.0 & 2.5 & 0.35 & 26.2 & 27.6 & 2.47 & $<0.001$ & 25.6 & 25.8 & 2.5 & 0.17 & 24.6 & 25.5 & 2.1 & 0.16 \\
\hline Milk fat, $\%$ & 3.61 & 3.7 & 0.11 & 0.13 & 3.90 & 3.84 & 0.14 & 0.56 & 4.39 & 4.04 & 0.22 & 0.12 & 3.48 & 3.5 & 0.12 & 0.39 & 3.98 & 3.90 & 0.25 & 0.24 \\
\hline Milk True Prot, ${ }^{1} \%$ & 2.81 & 2.90 & 0.05 & 0.07 & 2.90 & 2.97 & 0.070 & 0.22 & 3.08 & 3.12 & 0.120 & 0.20 & 2.64 & 2.71 & 0.19 & 0.024 & 3.23 & 3.30 & 0.12 & 0.04 \\
\hline Milk True Prot, kg & 0.894 & 0.912 & 0.04 & 0.07 & 0.934 & 0.862 & 0.078 & 0.18 & 0.774 & 0.835 & 0.086 & 0.02 & 0.926 & $0.949 \quad 0$ & 0.04 & 0.12 & 0.738 & 0.785 & 0.06 & 0.02 \\
\hline MP, g/d & 2055 & 2094 & 74 & 0.053 & 2090 & 2099 & 156 & 0.69 & 1778 & 1815 & 141 & 0.10 & 2134 & 214599 & 934 & 0.68 & 1809 & 2128 & 144 & $<0.001$ \\
\hline \multicolumn{21}{|l|}{ Duodenal } \\
\hline Arg, g/d & 125 & 126 & 6 & 0.28 & 124 & 123 & 12 & 0.82 & 103 & 104 & 8 & 0.13 & 118 & 118 & 8.0 & 0.90 & 114 & 129 & 10 & $<0.001$ \\
\hline His, g/d & 59 & 59 & 3 & 0.45 & 56 & 57 & 5 & 0.54 & 50 & 59 & 5 & $<0.01$ & 72 & 73 & 7.0 & 0.68 & 52 & 64 & 5 & $<0.001$ \\
\hline Ile, g/d & 133 & 134 & 5 & 0.14 & 137 & 136 & 10 & 0.38 & 117 & 119 & 8 & 0.59 & 155 & 152 & 9.0 & 0.52 & 122 & 141 & 10 & $<0.001$ \\
\hline Leu, g/d & 217 & 220 & 8 & 0.22 & 223 & 218 & 18 & 0.11 & 188 & 193 & 16 & 0.09 & 231 & 235 & 14.0 & 0.17 & 198 & 230 & 18 & $<0.001$ \\
\hline Lys, g/d & 174 & 178 & 7 & 0.14 & 165 & 189 & 11 & 0.003 & 163 & 165 & 16 & 0.62 & 151 & 169 & 12.0 & $<0.001$ & 151 & 183 & 12 & $<0.001$ \\
\hline Met, g/d & 49 & 66 & 2 & $<0.001$ & 53 & 53 & 5 & 0.83 & 53 & 54 & 8 & 0.09 & 68 & 75 & 7.0 & $<0.001$ & 43 & 55 & 4 & $<0.001$ \\
\hline Phe, g/d & 133 & 135 & 5 & 0.21 & 139 & 137 & 12 & 0.39 & 114 & 116 & 8 & 0.12 & 140 & 139 & 6.0 & 0.64 & 118 & 139 & 9 & $<0.001$ \\
\hline Thr, g/d & 129 & 130 & 5 & 0.24 & 130 & 129 & 9.0 & 0.72 & 112 & 114 & 7 & 0.13 & 120 & 120 & 10.0 & 0.94 & 115 & 133 & 8 & $<0.001$ \\
\hline \multirow{2}{*}{\multicolumn{21}{|c|}{ Plasma (AA) }} \\
\hline & & & & & & & & & & & & & & & & & & & & \\
\hline $\mathrm{Arg}, \mu M$ & 84.7 & 85.3 & 8.6 & 0.76 & 73.7 & 78.3 & 6.7 & 0.23 & 74.0 & 74.7 & 5.7 & 0.85 & 81.1 & 83.8 & 8.3 & 0.20 & 75.1 & 81.5 & 4.2 & 0.11 \\
\hline His, $\mu M$ & 46.1 & 41.2 & 3.2 & $<0.001$ & 43.9 & 37.9 & 5.3 & 0.004 & 20.5 & 50.0 & 6.0 & 0.01 & 52.2 & 49.6 & 4.4 & 0.18 & 35.90 & 45.80 & 3.2 & $<0.001$ \\
\hline Ile, $\mu M$ & 116.0 & 110.3 & 4.3 & 0.03 & 123.8 & 132.6 & 12.3 & 0.52 & 106.9 & 111.8 & 8.8 & 0.16 & 111.2 & 112.70 & 4.2 & 0.68 & 105.90 & 131.7 & 9.5 & $<0.001$ \\
\hline Leu, $\mu M$ & 161.5 & 149.1 & 11.6 & $<0.001$ & 149.9 & 137.6 & 21.5 & 0.32 & 123.0 & 113.9 & 1.8 & 0.13 & 133.1 & 142.5 & 11.7 & 0.22 & 127.3 & 170.5 & 15.8 & $<.0001$ \\
\hline Lys, $\mu M$ & 81.4 & 80.2 & 5.2 & 0.41 & 63.5 & 93.1 & 8.4 & 0.002 & 74.0 & 79.7 & 5.3 & 0.15 & 64.8 & 77.9 & 6.2 & $<0.001$ & 67.9 & 89.1 & 5.8 & $<0.001$ \\
\hline Met, $\mu M$ & 24.4 & 34.2 & 2.9 & $<0.001$ & 26.1 & 23.6 & 4.2 & 0.42 & 34.1 & 33.9 & 10.3 & 0.86 & 28.4 & 34.9 & 2.7 & 0.003 & 19.6 & 22.6 & 1.2 & $<0.001$ \\
\hline Phe, $\mu M$ & 51.3 & 48.8 & 2.4 & 0.01 & 53.6 & 50.1 & 6.4 & 0.06 & 47.6 & 44.4 & 6.6 & 0.20 & 54.4 & 53.2 & 3.1 & 0.38 & 47.3 & 52.1 & 4.7 & 0.018 \\
\hline Thr, $\mu M$ & 94.6 & 90.3 & 6.4 & 0.04 & 115.7 & 110.5 & 14.2 & 0.22 & 104.2 & 114.9 & 6.2 & 0.13 & 107.7 & $104.8 \&$ & 8.6 & 0.20 & 93.9 & 10.3 & 7.2 & $<0.001$ \\
\hline Val, $\mu M$ & 239.3 & 222.8 & 15.7 & $<0.001$ & 227.5 & 243.1 & 27.7 & 0.13 & 217.6 & 215.7 & 31.2 & 0.78 & 196.2 & 194.2 & 21.4 & 0.62 & 212.5 & 280.1 & 24.8 & $<0.001$ \\
\hline
\end{tabular}

${ }^{1}$ Milk true protein $=$ milk $\mathrm{CP}-\mathrm{NPN}$. 

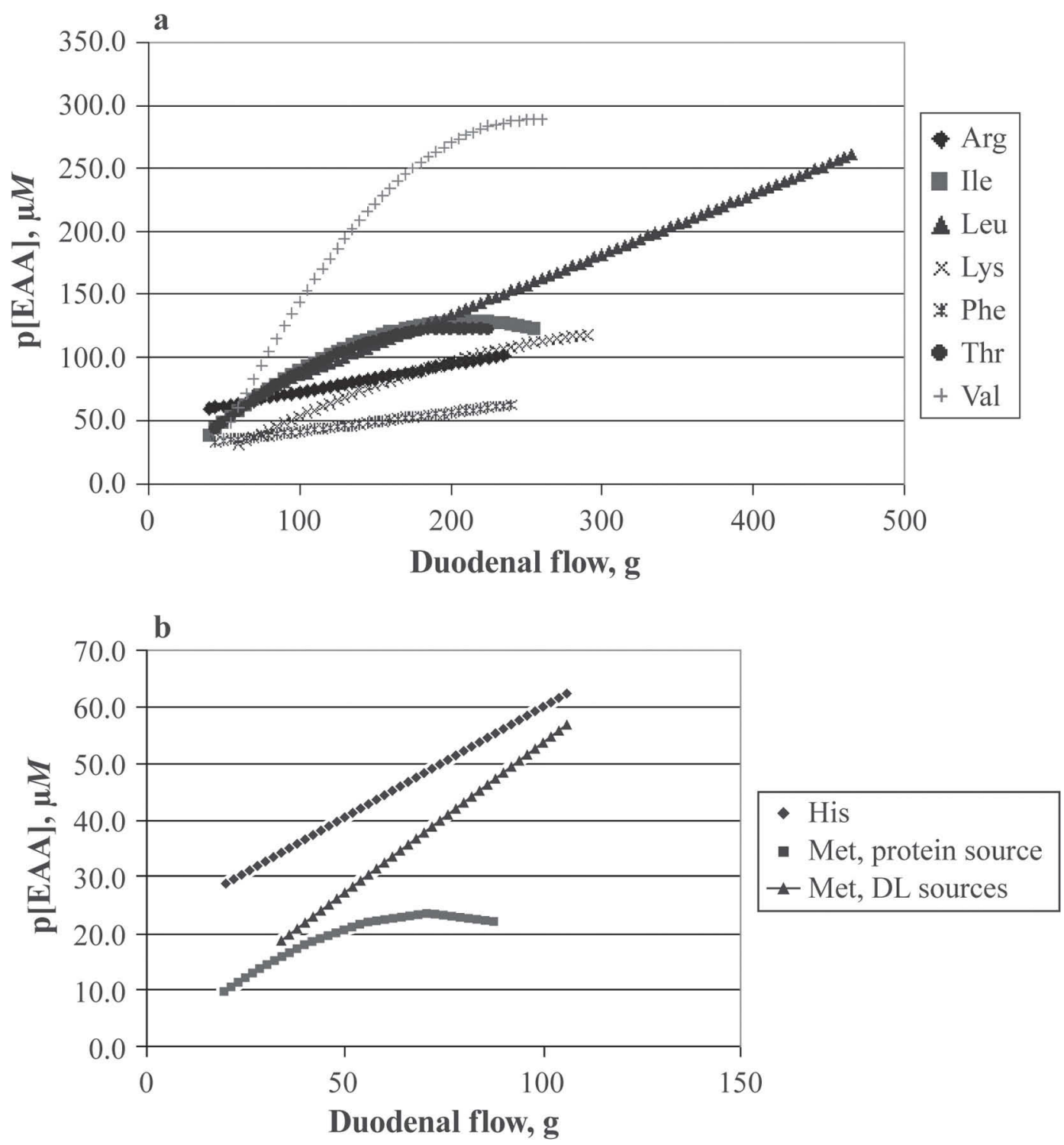

Figure 3. (a) Regression plot of association of duodenal flow of major quantities of EAA with plasma AA concentration (p[EAA], $\mu M$ ) over the range of observed data. (b) Regression plot of association of duodenal flow of His, and Met from 2 sources with plasma AA concentration $(\mathrm{p}[\mathrm{EAA}], \mu M)$ over the range of observed data.

Little evidence exists that breed or stage of lactation has an influence on $\mathrm{p}[\mathrm{EAA}]$, although breed effects on milk protein percent are well known (NRC, 2001) and cows are in negative protein balance early in lactation (Doepel et al., 2002). This suggests EAA-sparing mechanisms, EAA mobilization, or both can buffer the effect of reduced duodenal supply on p[EAA]. Also, DMI, milk production, milk protein yield, and energy intake had very little effect on $\mathrm{p}[\mathrm{EAA}]$ once AAduo was accounted for. Prior studies have associated DMI with increased milk yield, whereas increased milk production and energy intake have been associated with increases in milk protein yield (Hristov et al., 2004). However, these effects do not seem to be reflected in p[EAA]. Using developmental equations to predict $\mathrm{p}[\mathrm{EAA}]$ in the validation database gave consistent agreement with the observed values, as well as with the adj $\mathrm{R}^{2}$ and $\mathrm{RMSE}$ from the developmental database (Table 11). In all cases these equations were useful for predicting $\mathrm{p}[\mathrm{EAA}]$ if not with great precision. Although expressing duodenal flow as a percent of MP appeared to slightly improve association between duodenal flow and $\mathrm{p}[\mathrm{Arg}], \mathrm{p}[\mathrm{Leu}]$, and $\mathrm{p}[\mathrm{Lys}]$ in the development database, adding these terms to the equations actually lowered both the accuracy and precision of predicting $\mathrm{p}[\mathrm{EAA}]$ compared with the EAAduo (Table 11) for all EAA in the validation 
database. Thus, for predicting p[EAA], use of EAAduo is a better alternative than using EAA_MP.

The fact that MTP_MP was significant only for Lys and Phe in the mixed equation suggests that $\mathrm{p}[\mathrm{EAA}]$ may be more reflective of duodenal supply than for milk protein output. Further, other than for Leu and Val (Figure 3a), p[EAA] appear to be rather tightly held over a rather wide range of duodenal flow as observed in this database. The observation that $\mathrm{p}$ [Val] displayed a slope $>1$ in relation to Valduo, but a slope decrease of 3.6 as MTP_MP increased is intriguing, although it remains unexplained. Several lines of reasoning, including the intercept of the linear EAAduo equations and the nadir of the branched-chain AA with increasing MTP_MP, leads to the inevitable conclusion that each $\mathrm{p}[\mathrm{EAA}]$ is regulated in a unique manner specific to that EAA or that group of AA. Indeed, recent studies have shown that an imbalance in one branched-chain AA can affect the concentrations of the other branchedchain AA (Doelman et al., 2014), perhaps because they share the same dehydrogenase for their catabolism.

The response of single EAA addition on the plasma concentrations of other EAA is of interest. When His or Met+Lys was added singly, an increase in plasma concentration of only the added EAA was observed. But addition of either Lys or Met alone caused significant changes in several p[EAA]. Moreover, Met appeared to be much more potent in this respect, causing a decrease in the concentration of all EAA except Arg and Lys, whereas addition of Lys only decreased only His and Phe. When infusing His, Lys, or Met directly into the venous plasma supply, Fisher (1972) found similar changes. The predicted flow of Met and Lys were slightly greater in the single addition than in the addition of Lys + Met (24 vs. $18 \mathrm{~g}$ of Lys and 17 vs. $7 \mathrm{~g}$ of Met for single addition vs. Lys + Met addition). This suggests the possibility that quantity of the addition might have an effect on the $\mathrm{p}[\mathrm{EAA}]$ response. However, when tested across the whole database, no association was found between flows of Lys and Met, expressed either as duodenal flow or as percent of MP (data not shown) and $\mathrm{p}[\mathrm{EAA}]$. This suggests that factors beyond the influence of the amount Lys or Met influenced the plasma response to increases in these EAA. Other explanations could be that mass of Met or Lys added to the duodenal flow prevented the absorption of other AA (Baumrucker, 1985). It could also be that the Lys or Met stimulated MPY, which in turn demanded more EAA from plasma. It could also be that Lys or Met increased tissue synthesis requiring more EAA from plasma. In any case, this observation indicates that His has the potential to become limiting when limitation of Met or Lys supply is relieved. Although the lactating goat appears to have a great ability to increase the efficiency of His use in support of lactation, a supply shortage still negatively affected milk protein yield (Bequette et al., 2000).

Interestingly, when both Lys and Met are added in the single addition database, the only effects appeared as increments in $\mathrm{p}[\mathrm{Lys}]$ and $\mathrm{p}[\mathrm{Met}]$. Although it appears that EAAduo can cause changes in the plasma concentrations of several EAA, these changes do not seem to be consistent. These observations taken together suggest the existence of an optimum balance of duodenal AA and that this optimum balance is close to the EAA distribution of casein. However, the optimum EAA balance and amount relative to needs cannot be determined with plasma data.

At first it appears that calculated minimum $\mathrm{p}[\mathrm{EAA}]$ (as indicated by the intercept term of linear equations for association of EAAduo with $\mathrm{p}[\mathrm{EAA}]$ ) and the calculated maximum could provide estimates of minimum and maximum EAA calculations. However, estimates of $\mathrm{p}[\mathrm{EAA}]$ minimums and maximums are not consistent. For example, p[Thr] minimum was estimated as 55.1 $\mu M$ and the maximum at $126.2 \mu M$ using the association between EAAduo and $\mathrm{p}[\mathrm{EAA}]$, but the minimum was $79.0 \mu M$ and the maximum $97.6 \mu M$ when associating MPY_MP with p[EAA], both taken from the same database. This appears to be further evidence that EAA requirements cannot be described from plasma concentrations.

The results of additions of Hisduo are most interesting in comparison with the other EAAduo. Flows of all EAAduo except Ileduo were increased when Hisduo was increased. This was due to an increase in DMI and resulted in more milk and milk protein, but no increase in milk protein percent. It is not known why Hisduo should cause an increase in DMI in lactating cows when it is known that His is a potent inhibitor of feed intake in rats either through formation of histamine (Kasaoka et al., 2004) or through conversion to histidine peptides (Olszewski et al., 2003). Increased Hisduo through rumen protected His (Lee et al., 2012; Giallongo et al., 2014) or through abomasal infusion (Lapierre et al., 2014; Ouellet et al., 2014) increased DMI, whereas both Weekes et al. (2006) and Stahel et al. (2014) reported a drop in DMI when His was deficient. With only 8 comparisons in the present study, it will take more controlled experiments, preferably with other ruminants and nonlactating cattle, to ferret out whether Hisduo causes an increase in feed consumption. No matter how these increases in duodenal flow came about, they resulted only in higher $\mathrm{p}[\mathrm{His}]$ as other $\mathrm{p}[\mathrm{EAA}]$ were unchanged due to His addition. This may be due to an unchanged partial efficiency of AA use associated with 
increased DMI and MPY relative to a relatively large supply of His.

Dramatic changes in $\mathrm{p}[\mathrm{EAA}]$ reported in monogastric species (Forslund et al., 2000; Burke et al., 2012) do not appear in this database for dairy cattle. This may be because of the more or less constant flow of nutrients supplied to the ruminant (Nocek and Braund, 1985) and the relatively small range of dietary protein tested in dairy rations generally and in the current database (Table 3). Why primiparous cows have a greater $\mathrm{p}[\mathrm{Arg}]$ than older cows is unclear. It might be supposed that because primiparous cows have significantly less milk production, and there appears to be a high demand for Arg for milk (Lapierre et al., 2012b), this may only reflect the relative demand for Arg. However, it is not clear why other EAA did not show similar trends. Demand of EAA requirement for growth and a correspondingly lower DMI and microbial synthesis would seem to exacerbate the EAA deficiencies. Although the lack of breed effects on $\mathrm{p}[\mathrm{EAA}]$ might be expected, the lack of DIM effects are puzzling. The range of milk production and feed intake across all stages of lactation, as well as the use of study as a random effect, may have combined to mask any association with DIM. In the relatively large number of studies with cows in early lactation, a time when cows are known to be in negative energy and protein balance (Doepel et al., 2002), it was expected to find that $\mathrm{p}[\mathrm{EAA}]$ were diminished in early lactation. This was not observed. Even when DIM was the only term in the model besides study as random, DIM never had a significant effect on any $\mathrm{p}$ [EAA]. This observation confirms that of Foldager et al. (1980) who found no effect on plasma AA due to stage of lactation, although differences have been found between lactating and dry cows (Doepel et al., 2009) as well as transition cows (Meijer et al., 1995). The study of Meijer et al. (1995) also leads to the conclusion that as lactation progresses, the $\mathrm{p}[\mathrm{EAA}]$ are rather tightly held in spite of initially increasing and then decreasing DMI. In humans p[EAA] are tightly held, particularly as the dietary flow diminishes (Milsom et al., 1979); this may be similar in lactating cattle.

Overall, explanations for the changes in $\mathrm{p}[\mathrm{EAA}]$ beyond EAAduo are difficult and must remain speculative. Although some of the EAA appear to be used as energy sources by gut tissue (Raggio et al., 2004) and use of AA for gluconeogenesis is high in some metabolic states (Bell, 1995), use of AA for gluconeogenesis is ordinarily low depending on the balance between somatotropin and insulin (Lobley, 1992).

Because p $[\mathrm{EAA}]$ did not indicate EAA requirements, nor were changes in $\mathrm{p}[\mathrm{EAA}]$ evident for cow factors and ration components, differences observed for breed and stage of lactation effects on milk protein yield observed in other studies might be reflected either in plasma flow through the mammary gland or in differential extraction of individual $\mathrm{p}[\mathrm{EAA}]$.

\section{CONCLUSIONS}

This meta-analysis study indicates that $\mathrm{p}[\mathrm{EAA}]$ can most efficiently be modeled as linear functions of AAduo. Further, no evidence was found of break points or that $\mathrm{p}[\mathrm{EAA}]$ is in any way related to EAA requirements for lactation, at least under the conditions of studies used in the current study. Additions of Lys and Met alone, but not together, perturb p[EAA]. Breed differences and stage of lactation effects on milk protein production appear related to either EAA extraction or plasma flow through the udder as they do not appear to be related to $\mathrm{p}[\mathrm{EAA}]$.

\section{ACKNOWLEDGMENTS}

The authors thank J. R. Patton (NittanyCow Software Services, Mifflinburg, PA) for help with editing the manuscript as well as Evonik AG for partial funding.

\section{REFERENCES}

Baumrucker, C. R. 1985. Amino acid transport systems in bovine mammary tissue. J. Dairy Sci. 68:2436-2451.

Bell, A. W. 1995. Regulation of organic nutrient metabolism during transition from late pregnancy to early lactation. J. Anim. Sci. 73:2804-2819

Bequette, B. J., M. D. Hanigan, A. G. Calder, C. K. Reynolds, G. E. Lobley, and J. C. MacRae. 2000. Amino acid exchange by the mammary gland of lactating goats when histidine limits milk production. J. Dairy Sci. 83:765-775.

Bibby, J., and H. Toutenburg. 1977. Chapter 1: Basic ideas. Pages 16-19 in Prediction and Improved Estimation in Linear Models. John Wiley \& Sons, London, UK.

Broderick, G. A., L. D. Satter, and A. E. Harper. 1974. Use of plasma amino acid concentration to identify limiting amino acids for milk production. J. Dairy Sci. 57:1015-1023.

Burke, L. M., J. A. Winter, D. Cameron-Smith, M. Enslen, M. Farnfield, and J. Decombaz. 2012. Effect of intake of different protein sources on plasma amino acid profiles at rest and after exercise. Int. J. Sport Nutr. Exerc. Metab. 22:452-462.

Clark, J. H., T. H. Klusmeyer, and M. R. Cameron. 1992. Microbial protein synthesis and flows of nitrogen fractions to the duodenum of dairy cows. J. Dairy Sci. 75:2304-2323.

Dalbach, K. F., M. Larsen, B. M. L. Raun, and N. B. Kristensen. 2011. Effects of supplementation with 2-hydroxy-4-(methylthio)butanoic acid isopropyl ester on splanchnic amino acid metabolism and essential amino acid mobilization in postpartum transition Holstein cows. J. Dairy Sci. 94:3913-3927.

Doelman, J., R. V. Curtis, M. Carson, J. J. M. Kim, J. P. Cant, and J. A. Metcalf. 2014. Milk protein synthesis is regulated by lysine and branched chain amino acid deficiencies in lactating mammary glands. J. Dairy Sci. 97(E-Suppl. 1):205. (Abstr.)

Doepel, L., H. Lapierre, and J. J. Kennelly. 2002. Peripartum performance and metabolism of dairy cows in response to prepartum energy and protein intake. J. Dairy Sci. 85:2315-2334. 
Doepel, L., G. E. Lobley, J. F. Bernier, P. Dubreuil, and H. Lapierre. 2009. Differences in splanchnic metabolism between late gestation and early lactation dairy cows. J. Dairy Sci. 92:3233-3243.

Evonik Industries. 2012. AminoCow Help-Formulas. AminoCow, the Mepron Dairy Ration Evaluator version 3.5.2. Evonik Industries, Hanau, Germany.

Fisher, L. J. 1972. Response of lactating cows to the intravenous infusion of amino acids. Can. J. Anim. Sci. 52:377-384.

Foldager, J., J. T. Huber, and W. G. Bergen. 1980. Factors affecting amino acids in blood of dairy cows. J. Dairy Sci. 63:396-404.

Forslund, A. H., L. Hambraeus, H. van Beurden, U. Holmack, A. E. El-Khoury, G. Hjorth, R. Olsson, M. Stridsberg, L. Wide, T. Akerfeldt, M. Regan, and V. R. Young. 2000. Inverse relationship between protein intake and plasma free amino acids in healthy men at physical exercise. Am. J. Physiol. Endocrinol. Metab. 278:E857-E867.

Garlick, P. J. 1980. Assessment of protein metabolism in the intact animal. Pages 51-67 in Protein Deposition in Animals. P. J. Buttery and D. B. Lindsay, ed., Butterworth, London, UK.

Giallongo, F., J. Oh, T. Frederick, H. Weeks, A. N. Hristov, H. Lapierre, R. A. Patton, A. Gehman, and C. Parys. 2014. Effects of slow release urea, rumen-protected methionine, and histidine on performance of dairy cows fed metabolizable protein-deficient diets. J. Dairy Sci. 97(E-Suppl. 1):174.

Gill, J. L. 1976. Design and Analysis of Experiments in the Animal and Medical Sciences. Iowa State University Press, Ames, IA.

Hristov, A. N., W. J. Price, and B. Shafii. 2004. A meta-analysis examining the relationship among dietary factors, dry matter intake, and milk and milk protein yield in dairy cows. J. Dairy Sci. $87: 2184-2196$

Kasaoka, S., N. Tsuboyama-Kasaoka, Y. Kawahara, S. Inoue, M. Tsuji, O. Ezaki, H. Kato, T. Tsuchiya, H. Okuda, and S. Nakajima. 2004. Histidine supplementation suppresses food intake and fat accumulation in rats. Nutrition 20:991-996.

Lapierre, H., G. Holtrop, A. G. Calder, J. Renaud, and G. E. Lobley. 2012a. Is D-methionine bio-available to the dairy cow? J. Dairy Sci. 95:353-362.

Lapierre, H., G. E. Lobley, L. Doepel, G. Raggio, H. Rulquin, and S. Lemosquet. 2012b. Triennial Lactation Symposium: Mammary metabolism of amino acids in dairy cows. J. Anim. Sci. 90:17081721

Lapierre, H., D. R. Ouellet, and G. E. Lobley. 2014. Estimation of histidine requirement in lactating dairy cows. J. Dairy Sci. 97(ESuppl. 1):757

Lean, I. J., A. R. Rabiee, T. F. Duffield, and I. R. Dohoo. 2009. Invited review: Use of meta-analysis in animal health and reproduction: Methods and applications. J. Dairy Sci. 92:3545-3565.

Lee, C., A. N. Hristov, T. W. Cassidy, K. S. Heyler, H. Lapierre, G. A Varga, M. J. de Veth, R. A. Patton, and C. Parys. 2012. Rumenprotected lysine, methionine, and histidine increase milk protein yield in dairy cows fed a metabolizable protein-deficient diet. J. Dairy Sci. 95:6042-6056.

Linzell, J. L. 1974. Mammary blood flow and methods of identifying and measuring precursors of milk. Pages 143-225 in Lactation. Vol. I. B. L. Larson and V. R. Smith, ed. Academic Press, New York, NY

Lobley, G. E. 1992. Control of the metabolic fate of amino acids in ruminants: A review. J. Anim. Sci. 70:3264-3275.

Meijer, G. A. L., J. Van der Meulen, J. G. M. Bakker, C. J. Van der Kelen, and A. M. Van Vuuren. 1995. Free amino acids in plasma and muscle of high yielding dairy cows in early lactation. J. Dairy Sci. 78:1131-1141

Milsom, J. P., M. Y. Morgan, and S. Sherlock. 1979. Factors affecting plasma amino acids concentrations in control subjects. Metabolism 28:313-319.

Moore, D. R., M. J. Robinson, J. L. Fry, J. E. Tang, E. I. Glover, S. B. Wilkinson, T. Prior, M. A. Tarnopolsky, and S. M. Phillips. 2009. Ingested protein dose response of muscle and albumin protein synthesis after resistance exercise in young men. Am. J. Clin. Nutr. 89:161-168.
NRC. 2001. Nutrient Requirements of Dairy Cattle. 7th rev. ed. Natl. Acad. Sci., Washington, DC.

Nocek, J. E., and D. G. Braund. 1985. Effect of feeding frequency on diurnal dry matter and water consumption, liquid dilution rate, and milk yield in first lactation. J. Dairy Sci. 68:2238-2247.

Olszewski, P. K., M. M. Wirth, T. J. Shaw, M. K. Grace, and A. S. Levine. 2003. Effect of peptide histidine isoleucine on consummatory behavior in rats. Am. J. Physiol. Regul. Integr. Comp. Physiol. 284:R1445-R1453.

Ouellet, D. R., G. E. Lobley, and H. Lapierre. 2014. Histidine requirement of dairy cows determined by the indicator amino acid oxidation (AAO) technique. J. Dairy Sci. 79(E-Suppl. 1):757.

Pacheco, D., R. A. Patton, C. Parys, and H. Lapierre. 2012. Ability of commercially available dairy ration programs to predict duodenal flows of protein and essential amino acids in dairy cows. J. Dairy Sci. 95:937-963.

Pacheco, D., C. G. Schwab, R. Berthiaume, G. Raggio, and H. Lapierre. 2006. Comparison of net portal absorption with predicted flow of digestible amino acids: A scope for improving current models? J. Dairy Sci. 89:4747-4757.

Patton, R. A. 2009. The strategic use of ruminally protected amino acids in dairy nutrition. Pages $39-51$ in Proc. Florida Ruminant Nutrition Conf. Univ. Florida, Gainesville.

Patton, R. A. 2010. Effect of rumen-protected methionine on feed intake, milk production, true milk protein concentration, and true milk protein yield, and the factors that influence these effects: A meta-analysis. J. Dairy Sci. 93:2105-2118.

Raggio, G., S. Lemosquet, G. E. Lobley, H. Rulquin, and H. Lapierre. 2006. Effect of casein and propionate supply on mammary protein metabolism in lactating dairy cows. J. Dairy Sci. 89:4340-4351.

Raggio, G., D. Pacheco, R. Berthiaume, G. E. Lobley, D. Pellerin, G. Allard, P. Dubreuil, and H. Lapierre. 2004. Effect of level of metabolizable protein on splanchnic flux of amino acids in lactating dairy cows. J. Dairy Sci. 87:3461-3472.

Rulquin, H., and L. Delaby. 1997. Effects of the energy balance of dairy cows on lactational responses to rumen-protected methionine. J. Dairy Sci. 80:2513-2522.

St-Pierre, N. R. 2001. Integrating quantitative findings from multiple studies using mixed model methodology. J. Dairy Sci. 84:741-755.

Stahel, P., N. G. Purdie, and J. P. Cant. 2014. Use of dietary feather meal to induce histidine deficiency or imbalance in dairy cows and effects on milk composition. J. Dairy Sci. 97:439-445.

Swanson, E. W. 1977. Factors for computing requirements of protein for maintenance of cattle. J. Dairy Sci. 60:1583-1593.

Trottier, N. L., C. F. Shipley, and R. A. Easter. 1997. Plasma amino acid uptake by the mammary gland of the lactating sow. J. Anim. Sci. 75:1266-1278.

Weekes, T. L., P. H. Luimes, and J. P. Cant. 2006. Responses to amino acid imbalances and deficiencies in lactating dairy cows. J. Dairy Sci. 89:2177-2187.

Yeo, J.-M., C. H. Knight, and D. G. Chamberlain. 2003. Effects of changes in dietary amino acid balance on milk yield and mammary function in dairy cows. J. Dairy Sci. 86:1436-1444.

\section{Appendix A: Studies Used in the Developmental Data Set (Table 1).}

1. Awawdeh, M. S., E. C. Titgemeyer, J. S. Drouillard, R. S. Beyer and J. E. Shirley. 2007. Ruminal degradability and lysine bioavailability of soybean meals and effects on performance of dairy cows. J. Dairy Sci. 90:4740-4753.

2. Bach, A., G. B. Huntington, S. Calsamiglia, and M. D. Stern. 2000 Nitrogen metabolism of early lactation cows fed diets with two different levels of protein and different amino acid profiles. J. Dairy Sci. 83:2585-2595.

3. Bertrand, J. A., F. E. Pardue, and T. C. Jenkins. 1998. Effect of ruminally protected amino acids on milk yield and composition of Jersey cows fed whole cottonseed. J. Dairy Sci. 81:2215-2220. 
4. Berthiaume, R., P. Dubreuil, M. Stevenson, B. W. McBride, and H. Lapierre. 2001. Intestinal disappearance and mesenteric and portal appearance of amino acids in dairy cows fed ruminally protected methionine. J. Dairy Sci. 84:194-203.

5. Berthiaume, R., M. C. Thivierge, R. A. Patton, P. Dubreuil, M. Stevenson, B. W. McBride, and H. Lapierre. 2006. Effect of ruminally protected methionine on splanchnic metabolism of amino acids in lactating dairy cows. J. Dairy Sci. 89:1621-1634.

6. Blauwiekel, R., S. Xu, J. H. Harrison, K. A. Loney, R. E. Riley, and M. C. Calhoun. 1997. Effect of whole cottonseed, gossypol and ruminally protected lysine supplementation on milk yield and composition. J. Dairy Sci. 80:1358-1365.

7. Blouin, J. P., J. F. Bernier, C. K. Reynolds, G. E. Lobley, P. Dubreuil, and H. Lapierre. 2002. Effect of supply of metabolizable protein on splanchnic fluxes of nutrients and hormones in lactating dairy cattle. J. Dairy Sci. 85:2618-2630.

8. Blum, J. W., R. M. Bruckmaier, and F. Jans. 1999. Rumen-protected methionine fed to dairy cows: Bioavailability and effects on plasma amino acid pattern and plasma metabolite and insulin concentrations. J. Dairy Sci. 82:1991-1998.

9. Borucki Castro, S. I., L. E. Phillip, H. Lapierre, P. W. Jardon, and R. Berthiaume. 2008. The relative merit of ruminal undedgradable protein from soybean meal or soluble fiber from beet pulp to improve nitrogen utilization in dairy cows. J. Dairy Sci. 91:39473957.

10. Boucher, S. E., R. S. Ordway, N. L. Whitehouse, F. P. Lundy, P. J. Kononoff, and C. G. Schwab. 2007. Effect of incremental urea supplementation of a conventional corn silage-based diet on ruminal ammonia concentration and synthesis of microbial protein. J. Dairy Sci. 90:5619-5633.

11. Bremmer, D. R., T. R. Overton, and J. H. Clark. 1997. Production and composition of milk from Jersey cows administered bovine somatotropin and fed ruminally protected amino acids. J. Dairy Sci. 80:1374-1380.

12. Brito, A. F., G. F. Tremblay, A. Bertrand, Y. Castonguay, G. Belanger, R. Michaud, H. Lapierre, C. Benchaar, H. V. Petit, D. R. Ouellet, and R. Berthiaume. 2008. Alfalfa cut at sundown and harvested as baleage improves milk yield of late-lactation dairy cows. J. Dairy Sci. 91:3968-3982.

13. Broderick, G. A. 1986. Relative value of solvent and expeller soybean meal for lactating dairy cows. J. Dairy Sci. 69:2948-2958.

14. Broderick, G. A., W. M. Craig, and D. B. Ricker. 1993. Urea versus true protein as supplement for lactating dairy cows fed grain plus mixtures of alfalfa and corn silages. J. Dairy Sci. 76:2266-2274.

15. Cabrita, A. R. J., R. J. Dewhurst, D. S. P. Melo, J. M. Moorby, and A. J. M. Fonseca. 2011. Effects of dietary protein concentration and balance of absorbable amino acids on productive responses of dairy cows fed corn silage-based diets. J. Dairy Sci. 94:4647-4656.

16. Cant, J. P., E. J. DePeters, and R. L. Baldwin. 1993. Mammary amino acid utilization in dairy cows fed fat and its relationship to milk protein depression. J. Dairy Sci. 76:762-774.

17. Carvalho, L. P. F., A. R. Cabrita, R. J. Dewhurst, T. E. J. Vicente, Z. M. C. Lopes, and A. J. M. Fonseca. 2006. Evaluation of palm kernel meal and corn distillers grains in corn silage-based diets for lactating dairy cows. J. Dairy Sci. 89:2705-2715.

18. Chan, S. C., J. T. Huber, C. B. Theurer, Z. Wu, K. H. Chen, and J. M. Simas. 1997. Effects of supplemental fat and protein source on ruminal fermentation and nutrient flow to the duodenum in dairy cows. J. Dairy Sci. 80:152-159.

19. Christen, K. A., D. J. Schingoethe, K. F. Kalscheur, A. R. Hippen, K. K. Karges, and M. L. Gibson. 2010. Response of lactating dairy cows to high protein distillers grains or 3 other protein supplements. J. Dairy Sci. 93:2095-2104.

20. Christensen, R. A., M. R. Cameron, J. H. Clark, J. K. Drackley, J. M. Lynch, and D. M. Barbano. 1994. Effects of amount of protein and ruminally protected amino acids in the diet of dairy cows fed supplemental fat. J. Dairy Sci. 77:1618-1629.

21. Christensen, R. A., T. R. Overton, J. H. Clark, J. K. Drackley, D. R. Nelson, and S. A. Blum. 1996. Effects of dietary fat with or without nicotinic acid on nutrient flow to the duodenum of dairy cows. J. Dairy Sci. 79:1410-1424.
22. Colin-Schoellen, O., F. Laurent, B. Vignon, J. C. Robert, and B. Sloan. 1994. Interactions of ruminally protected methionine and lysine with protein source of energy level in the diets of cows. J. Dairy Sci. 78:2807-2818.

23. Dalbach, K. F., M. Larsen, B. M. L. Raun, and N. B. Kristensen. 2011. Effects of supplementation with 2-hydroxy-4-(methylthio)butanoic acid isopropyl ester on splanchnic amino acid metabolism and essential amino acid mobilization in postpartum transition Holstein cows. J. Dairy Sci. 94:3913-3927.

24. Davidson, S., B. A. Hopkins, D. E. Dias, S. M. Bolt, C. Brownie, V. Fellner, and L. W. Whitlow. 2003. Effects of amounts and degradability of dietary protein on lactation, nitrogen utilization, and excretion in early lactation Holstein cows. J. Dairy Sci. $86: 1681-1689$.

25. DeFrain, J. M., J. E. Shirley, E. C. Titgemeyer, A. F. Park, and R. T. Ethington. 2002. A pelleted combination of raw soyhulls and condensed corn steep liquor for lactating dairy cows. J. Dairy Sci. 85:3403-3410.

26. Dinn, N. E., J. A. Shelford, and J. L. Fisher. 1998. Use of the Cornell net carbohydrate and protein system and rumen-protected lysine and methionine to reduce nitrogen excretion from lactating dairy cows. J. Dairy Sci. 81:229-237.

27. Doepel, L., G. E. Lobley, J. F. Bernier, P. Dubreuil, and H. Lapierre. 2007. Effect of glutamine supplementation on splanchnic metabolism in lactating dairy cows. J. Dairy Sci. 90:4325-4339.

28. Doepel, L., and H. Lapierre. 2010. Changes in production and mammary metabolism of dairy cows in response to essential and nonessential amino acid infusions. J. Dairy Sci. 93:3264-3274.

29. Doepel, L., and H. Lapierre. 2011. Deletion of arginine from an abomasal infusion of amino acids does not decrease milk protein yield in Holstein cows. J. Dairy Sci. 94:864-873.

30. Donkin, S. S., G. A. Varga, T. F. Sweeney, and L. D. Muller. 1989. Rumen-protected methionine and lysine. Effects on animal performance, milk protein yield and physiological measures. J. Dairy Sci. 72:1484-1491.

31. Ellison Henson, J., D. J. Schingoethe, and H. A. Maiga. 1997. Lactational evaluation of protein supplements of varying ruminal degradabilities. J. Dairy Sci. 80:385-392.

32. Erickson, P. S., M. R. Murphy, and J. H. Clark. 1992. Supplementation of dairy cow diets with calcium salts of long-chain fatty acids and nicotinic acid in early lactation. J. Dairy Sci. 75:1078-1089.

33. Guinard, J., and H. Rulquin. 1994a. Effect of graded levels of duodenal infusions of casein on mammary uptake in lactating cows. 2. Individual amino acids. J. Dairy Sci. 77:3304-3315.

34. Guinard, J., and H. Rulquin. 1994b. Effects of graded amounts of duodenal infusions of lysine on the mammary uptake of major milk precursors in dairy cows. J. Dairy Sci. 77:3565-3576.

35. Guinard, J., and H. Rulquin. 1995. Effects of graded amounts of duodenal infusions of methionine on the mammary uptake of major milk precursors in dairy cows. J. Dairy Sci. 78:2196-2207.

36. Graulet, B., J. J. Matte, A. Desrochers, L. Doepel, M. F. Palin, and C. L. Girard. 2007. Effects of dietary supplements of folic acid and vitamin $\mathrm{B}_{12}$ on metabolism of dairy cows in early lactation. J. Dairy Sci. 90:3442-3455.

37. Hammon, H. M., C. C. Metges, P. Junghans, F. Becker, O. Bellmann, F. Schneider, G. Nurnberg, P. Dubreuil, and H. Lapierre. 2008. Metabolic changes and portal flux in dairy cows fed a ration containing rumen-protected fat as compared to a control diet. J. Dairy Sci. 91:208-217.

38. Hanigan, M. D., C. K. Reynolds, D. J. Humphries, B. Lupoli, and J. D. Sutton. 2004. A model of net amino acid absorption and utilization by the portal-drained viscera of the lactating dairy cow. J. Dairy Sci. 87:4247-4268.

39. Hu, W., M. R. Murphy, P. D. Constable, and E. Block. 2007a. Dietary cation-anion difference and dietary protein effects on performance and acid-base status of dairy cows in early lactation. J. Dairy Sci. 90:3355-3366.

40. Hu, W., M. R. Murphy, P. D. Constable, and E. Block. 2007b. Dietary cation-anion difference effects on performance and acidbase status of dairy cows postpartum. J. Dairy Sci. 90:3367-3375. 
41. Huhtanen, P., A. Vanhatalo, and T. Varvikko. 2001. Effects of abomasal infusions of histidine, glucose and leucine on milk production and plasma metabolites of dairy cows fed grass silage diets. J. Dairy Sci. 85:204-216.

42. Hurtaud, S., H. Rulquin, and R. Verite. 1998. Effects of graded duodenal infusions of glucose on yield and composition of milk from dairy cows. 1. Diets based on corn silage. J. Dairy Sci. 81:3239-3247.

43. Karunanandaa, K., L. E. Goodling, G. A. Varga, L. D. Muller, W. W. McNeill, T. W. Cassidy, and T. Lykos. 1994. Supplemental dietary fat and ruminally protected amino acids for lactating Jersey cows. J. Dairy Sci. 77:3417-3425.

44. King, K. J., J. T. Huber, M. Sadik, W. G. Bergen, A. L. Grant, and V. L. King. 1990. Influence of dietary protein sources on the amino acid profiles available for digestion and metabolism in lactating cows. J. Dairy Sci. 73:3208-3216.

45. Kleinschmit, D. H., D. J. Schingoethe, K. F. Kalscheur, and A. R Hippen. 2006. Evaluation of various sources of corn dried distillers grains plus solubles for lactating dairy cattle. J. Dairy Sci. 89:4784-4794.

46. Kleinschmit, D. H., D. J. Schingoethe, A. R. Hippen, and K. F. Kalscheur. 2007. Dried distillers grains plus solubles with corn silage or alfalfa hay as the primary forage source in dairy cow diets. J. Dairy Sci. 90:5587-5599.

47. Korhonen, M., A. Vanhatalo, T. Varvikko, and P. Huhtanen. 2000. Responses to graded postruminal doses of histidine in dairy cows fed grass silage diets. J. Dairy Sci. 83:2596-2608.

48. Korhonen, M., A. Vanhatalo, and P. Huhtanen. 2002. Evaluation of isoleucine, leucine and valine as a second-limiting amino acid for milk production in dairy cows fed grass silage diet. J. Dairy Sci. 85:1533-1545.

49. Korhonen, M., A. Vanhatalo, and P. Huhtanen. 2002. Effect of protein source on amino acid supply, milk production and metabolism of plasma nutrients in dairy cows fed grass silage. J. Dairy Sci. 85:3336-3351.

50. Kung, L., Jr., J. T. Huber, W. G. Bergen, and D. Petitclerc. 1984 Amino acids in plasma and duodenal digesta and plasma growth hormone in cows fed varying amounts of protein of differing degradability. J. Dairy Sci. 67:2519-2524.

51. LaCount, D. W., L. S. Emmert, and J. K. Drackley. 1996. Dose response of dairy cows to abomasal administration of four amounts of L-carnitine. J. Dairy Sci. 79:591-602.

52. LaCount, D. W., L. D. Ruppert, and J. K. Drackley. 1996. Ruminal degradation and dose response of dairy cows to dietary Lcarnitine. J. Dairy Sci. 79:260-269.

53. Lanham, J. K., C. E. Coppock, K. N. Brooks, D. L. Wilks, and J. L. Horner. 1992. Effects of whole cottonseed or niacin or both on casein synthesis by lactating Holstein cows. J. Dairy Sci. 75:184192.

54. Larsen, M., and N. B. Kristensen. 2009. Effect of abomasal glucose infusion on splanchnic amino acid metabolism in periparturient dairy cows. J. Dairy Sci. 92:3306-3318.

55. Lee, C., A. N. Hristov, K. S. Heyler, T. W. Cassidy, H. Lapierre, G. A. Varga, and C. Parys. 2012. Effects of metabolizable protein supply and amino acid supplementation on nitrogen utilization, milk production, and ammonia emissions from manure in dairy cows. J. Dairy Sci. 95:5253-5268.

56. Lee, C., A. N. Hristov, T. W. Cassidy, K. S. Heyler, H. Lapierre, G. A. Varga, M. J. de Veth, R. A. Patton, and C. Parys. 2012. Rumen-protected lysine, methionine, and histidine increase milk protein yield in dairy cows fed a metabolizable protein-deficient diet. J. Dairy Sci. 95:6042-6056.

57. Lemosquet, S., E. Delamaire, H. Lapierre, J. W. Blum, and J. L. Peyraud. 2009. Effects of glucose, propionic acid and nonessential amino acids on glucose metabolism and milk yield in Holstein dairy cows. J. Dairy Sci. 92:3244-3257.

58. Mackle, T. R., D. A. Dwyer, and D. E. Bauman. 1999. Effects of branched-chain amino acids and sodium caseinate on milk protein concentration and yield from dairy cows. J. Dairy Sci. 82:161-171.

59. Martineau, R., H. Lapierre, D. R. Ouellet, D. Pellerin, and R. Berthiaume. 2007. Effects of the method of conservation of timo- thy on nitrogen metabolism in lactating dairy cows. J. Dairy Sci 90:2870-2882

60. Martineau, R., C. Benchaar, H. V. Petit, H. Lapierre, D. R. Ouellet, D. Pellerin, and R. Berthiaume. 2007. Effects of lasalocid or monensin supplementation on digestion, ruminal fermentation, blood metabolites, and milk production of lactating dairy cows. J. Dairy Sci. 90:5714-5725.

61. Miettinen, H., and P. Huhtanen. 1996. Effects of the ratio of ruminal propionate to butyrate on milk yield and blood metabolites in dairy cows. J. Dairy Sci. 79:851-861.

62. Mjoun, K., K. F. Kalscheur, A. R. Hippen, D. J. Schingoethe, and D. E. Little. 2010. Lactation performance and amino acid utilization of cows fed increasing amounts of reduced-fat dried distillers grains with solubles. J. Dairy Sci. 93:288-303.

63. Mjoun, K., K. F. Kalscheur, A. R. Hippen, and D. J. Schingoethe. 2010. Performance and amino acid utilization of early lactation dairy cows fed regular or reduced-fat dried distillers grains with solubles. J. Dairy Sci. 93:3176-3191.

64. Moorby, J. M., R. J. Dewhurst, R. T. Evans, and W. J. Fisher. 2002. Effects of level of concentrate feeding during the second gestation of Holstein-Friesian dairy cows. 2. Nitrogen balance and plasma metabolites. J. Dairy Sci. 85:178-189.

65. Mulrooney, C. N., D. J. Schingoethe, K. F. Kalscheur, and A. R. Hippen. 2009. Canola meal replacing distillers grains with solubles for lactating dairy cows. J. Dairy Sci. 92:5669-5676.

66. Nagel, S. A., and G. A. Broderick. 1992. Effect of formic acid or formaldehyde treatment of alfalfa silage on nutrient utilization by dairy cows. J. Dairy Sci. 75:140-154.

67. Nichols, J. R., D. J. Schingoethe, H. A. Maiga, M. J. Brouk, and M. S. Piepenbrink. 1998. Evaluation of corn distillers grains and ruminally protected lysine and methionine for lactating dairy cows. J. Dairy Sci. 81:482-491.

68. Noftsger, S., N. R. St-Pierre, and J. T. Sylvester. 2005. Determination of rumen degradability and ruminal effects of three sources of methionine in lactating cows. J. Dairy Sci. 88:223-237.

69. Oba, M., G. B. Penner, T. D. Whyte, and K. Wierenga. 2010. Effects of feeding triticale dried distillers grains plus solubles as a nitrogen source on productivity of lactating dairy cows. J. Dairy Sci. 93:2044-2052.

70. Overton, T. R., D. W. LaCount, T. M. Cicela, and J. H. Clark. 1996. Evaluation of a ruminally protected methionine product for lactating dairy cows. J. Dairy Sci. 79:631-638.

71. Overton, T. R., L. S. Emmert, and J. H. Clark. 1998. Effects of source of carbohydrate and protein and rumen-protected methionine on performance of cows. J. Dairy Sci. 81:221-228.

72. Palmquist, D. L., and H. R. Conrad. 1982. Utilization of distillers dried grains plus solubles by dairy cows in early lactation. J. Dairy Sci. 65:1729-1733.

73. Piepenbrink, M. S., T. R. Overton, and J. H. Clark. 1996. Response of cows fed a low crude protein diet or ruminally protected methionine and lysine. J. Dairy Sci. 79:1638-1646.

74. Pisulewski, P. M., H. Rulquin, J. L. Peyraud, and R. Verite. 1996. Lactational and systemic responses of dairy cows to postruminal infusions of increasing amounts of methionine. J. Dairy Sci. 79:1781-1791

75. Preynat, A., H. Lapierre, M. C. Thivierge, M. F. Palin, J. J. Matte, A. Desrochers, and C. L. Girard. 2009. Effects of supplements of folic acid, vitamin $\mathrm{B}_{12}$, and rumen-protected methionine on whole body metabolism of methionine and glucose in lactating dairy cows. J. Dairy Sci. 92:677-689.

76. Preynat, A., H. Lapierre, M. C. Thivierge, M. F. Palin, J. J. Matte, A. Desrochers, and C. L. Girard. 2008. Influence of methionine supply on the response of lactational performance of dairy cows to supplementary folic acid and vitamin $B_{12}$. J. Dairy Sci. 92:16851695.

77. Raggio, G., D. Pacheco, R. Berthiaume, G. E. Lobley, D. Pellerin, G. Allard, P. Dubreuil, and H. Lapierre. 2004. Effect of level of metabolizable protein on splanchnic flux of amino acids in lactating dairy cows. J. Dairy Sci. 87:3461-3472.

78. Rius, A. G., M. L. McGilliard, C. A. Umberger, and M. D. Hanigan. 2010. Interactions of energy and predicted metabolizable pro- 
tein in determining nitrogen efficiency in the lactating dairy cow. J. Dairy Sci. 93:2034-2043.

79. Rius, A. G., J. A. D. R. N. Appuhamy, J. Cyriac, D. Kirovski, O. Becvar, J. Escobar, M. L. McGilliard, B. J. Bequette, R. M. Akers, and M. D. Hanigan. 2010. Regulation of protein synthesis in mammary glands of lactating dairy cows by starch and amino acids. J. Dairy Sci. 93:3114-3127.

80. Rogers, J. A., U. Krishnamoorthy, and C. J. Sniffen. 1987. Plasma amino acids and milk protein production by cows fed rumen-protected methionine and lysine. J. Dairy Sci. 70:789-798.

81. Rulquin, H., and L. Delaby. 1997. Effects of the energy balance of dairy cows on lactational responses to rumen-protected methionine. J. Dairy Sci. 80:2513-2522.

82. Schwab, C. G., C. K. Bozak, N. L. Whitehouse, and M. M. Mesbah. 1992. Amino acid limitation and flow to the duodenum at four stages of lactation. 1. Sequence of lysine and methionine limitation. J. Dairy Sci. 75:3486-3502.

83. Schwab, C. G., C. K. Bozak, N. L. Whitehouse, and V. M. Olson. 1992. Amino acid limitation and flow to the duodenum at four stages of lactation. 2. Extent of lysine limitation. J. Dairy Sci. 75:3503-3518.

84. Seymour, W. M., C. E. Polan, and J. H. Herbein. 1990. Effects of dietary protein degradability and casein or amino acid infusion on production and plasma amino acids in dairy cows. J. Dairy Sci. 73:735-748.

85. St-Pierre, N. R., and J. T. Sylvester. 2005. Effects of 2 hydroxy4-(methylthio) butanoic acid (HMB) and its isopropyl ester on milk production and composition by Holstein cows. J. Dairy Sci. 88:2487-2497.

86. Tagari, H., K. Webb Jr., B. Theurer, T. Huber, D. Deyoung, P. Cuneo, J. E. P. Santos, J. Simas, M. Sadik, A. Alio, O. Lozano, A. Delgado-Elorduy, L. Nussio, C. M. M. Bitar, and F. Santos. 2007. Mammary uptake, portal-drained visceral flux, and hepatic metabolism of free and peptide-bound amino acids in cows fed steamflaked or dry-rolled sorghum grain diets. J. Dairy Sci. 91:679-697.

87. Vanhatalo, A., P. Huhtanen, V. Toivonen, and T. Varvikko. 1999. Response of dairy cows fed grass silage diets to abomasal infusions of histidine alone or in combinations with methionine and lysine. J. Dairy Sci. 82:2674-2685.

88. Vanhatalo, A., K. Kuoppala, S. Ahvenjarvi, and M. Rinne. 2009. Effects of feeding grass or red clover silage cut at two maturity stages in dairy cows. 1. Nitrogen metabolism and supply of amino acids. J. Dairy Sci. 92:5620-5633.

89. Varvikko, T., A. Vanhatalo, T. Jalava, and P. Huhtanen. 1999. Lactation and metabolic responses to graded abomasal doses of methionine and lysine in cows fed grass silage diets. J. Dairy Sci. 82:2659-2673.

90. Vicini, J. L., J. H. Clark, W. L. Hurley, and J. M. Bahr. 1988. Effects of abomasal or intravenous administration of arginine on milk production, milk composition and concentrations of somatotropin and insulin in plasma of dairy cows. J. Dairy Sci. 71:658-665.

91. Wang, C., H. Y. Liu, Y. M. Wang, Z. Q. Yang, J. X. Lie, Y. M. Wu, T. Yan, and H. W. Ye. 2010. Effects of dietary supplementation of methionine and lysine on milk production and nitrogen utilization in dairy cows. J. Dairy Sci. 93:3661-3670.

92. Weekes, T. L., P. H. Luimes, and J. P. Cant. 2006. Responses to amino acid imbalances and deficiencies in lactating dairy cows. J. Dairy Sci. 89:2177-2187.

93. Wickersham, E. E., J. E. Shirley, E. C. Titgemeyer, M. J. Brouk, J. M. DeFrain, A. F. Park, D. E. Johnson, and R. T. Ethington. 2004. Response of lactating dairy cows to diets containing wet corn gluten feed or a raw soybean hull-corn steep liquor pellet. J. Dairy Sci. 87:3899-3911.

\section{Appendix B: Studies Used in the Validation Data Set (Table 2).}

1. Abu-Ghazaleh, A. A., D. J. Schingoethe, and A. R. Hippen. 2001. Blood amino acid and milk composition from cows fed soybean meal, fishmeal, or both. J. Dairy Sci. 84:1174-1181.
2. Broderick, G. A., L. D. Satter, and A. E. Harper. 1974. Use of plasma amino acid concentration to identify limiting amino acids for milk production. J. Dairy Sci. 57:1015-1023.

3. Casper, D. P., D. J. Schingoethe, C.-M. J. Yang, and C. R. Mueller. 1987. Protected methionine supplementation with extruded blend of soybeans and soybean meal for dairy cows. J. Dairy Sci. 70:321-330.

4. Casper, D. P., and D. J. Schingoethe. 1988. Protected methionine supplementation to a barley-based diet for cows during early lactation. J. Dairy Sci. 71:164-172.

5. Casper, D. P., D. J. Schingoethe, and W. A. Eisenbeisz. 1990. Response of early lactation cows to diets that vary in ruminal degradability of carbohydrates and amount of fat. J. Dairy Sci. $73: 425-444$.

6. Choi, C. W., A. Vanhatalo, S. Ahvenjarvi, and P. Huhtanen. 2002 Effects of several protein supplements on flow of soluble non-ammonia nitrogen from the forestomach and milk production in dairy cows. Anim. Feed Sci. Technol. 102:15-33.

7. Choung, J. J., and D. G. Chamberlain. 1993. The effects of abomasal infusions of casein or soya-bean-protein isolate on the milk production of dairy cows in mid-lactation. Br. J. Nutr. 69:103-115.

8. Clark, J. H., H. R. Spires, R. G. Derrig, and M. R. Bennink. 1977. Milk production, nitrogen utilization and glucose synthesis in lactating cows infused postruminally with sodium caseinate and glucose. J. Nutr. 107:631-644.

9. Coomer, C., H. E. Amos, C. C. Williams, and J. G. Wheeler. 1993 Response of early lactation cows to fat supplementation in diets with different nonstructural carbohydrate concentrations. J. Dairy Sci. 75:3747-3754.

10. Drackley, J. K., and D. J. Schingoethe. 1986. Extruded blend of soybean meal and sunflower seeds for dairy cattle in early lactation. J. Dairy Sci. 69:371-384.

11. Fathi Nasri, M. H., M. Danesh Mesgaran, E. Kebreab, and J. France. 2007. Past peak lactational performance of Iranian Holstein cows fed raw or roasted whole soybeans. Can. J. Anim. Sci. $87: 441-447$.

12. Garnsworthy, P. C., J. G. Gong, D. G. Armstrong, J. R. Newbold, M. Marsden, S. E. Richards, G. E. Mann, K. D. Sinclair, and R. Webb. 2008. Nutrition, metabolism, and fertility in dairy cows: 3. Amino acids and ovarian function. J. Dairy Sci. 91:4190-4197.

13. Hadrova, S., L. Krizova, M. Richter, J. Trinacty, and M. Drackova. 2012. The effect of duodenal infusion of histidine on milk yield, milk composition, and plasma amino acids in dairy cows. J. Anim. Feed Sci. 21:555-565.

14. Hadsell, D. L., and J. L. Sommerfeldt. 1988. Chickpeas as a protein and energy supplement for high producing dairy cows. J. Dairy Sci. $71: 762-772$

15. Haque, M. N., H. Rulquin, and S. Lemosquet. 2013. Milk protein responses in dairy cows to changes in post ruminal supplies of arginine, isoleucine and valine. J. Dairy Sci. 96:420-430.

16. Krizova, L., J. Trinacty, M. Richter, S. Hadrova, and J. Pozdisek. 2008. Effect of ruminally-protected leucine supplement on milk yield and plasma amino acids in dairy cows. Agric. Food Sci. $17: 351-359$.

17. Krober, T. F., M. Kreuzer, M. Senn, W. Langhans, and F. Sutter. 2000. Lactational and metabolic effects in cows of lysine and methionine added to a ration deficient according to the I.N.R.A. method. Arch. Anim. Nutr. 53:375-394.

18. Lapierre, H., L. Doepel, E. Milne, and G. E. Lobley. 2008. Responses in mammary and splanchnic metabolism to altered lysine supply in dairy cows. Animal 3:360-371.

19. Liu, C., D. J. Schingoethe, and G. A. Stegeman. 2000. Corn distillers grains versus a blend of protein supplements with or without ruminally protected amino acids for lactating cows. J. Dairy Sci. 83:2075-2084.

20. Maiga, H. A., and D. J. Schingoethe. 1997. Optimizing the utilization of animal fat and ruminal bypass proteins in the diets of lactating dairy cows. J. Dairy Sci. 80:343-352.

21. Miettinen, H. O., and P. J. Huhtanen. 1997. Effects of silage fermentation and post-ruminal casein supplementation in lactating 
dairy cows: 2-Energy metabolites and plasma amino acids. J. Sci. Food Agric. 74:459-468.

22. Pacheco-Rios, D., W. C. McNab, S. Cridland, T. N. Barry, and J. Lee. 1998. Arterio-venous differences of amino acids across the mammary gland of cows fed fresh pasture at two levels of dry matter intake during early lactation. Proc. N.Z. Soc. Anim. Prod. 58:98-101.

23. Papas, A. M., J. L. Vicini, J. H. Clark, and S. Peirce-Sandner. 1984. Effect of rumen-protected methionine on plasma free amino acids and production by dairy cows. J. Nutr. 114:2221-2227.

24. Piepenbrink, M. S., D. J. Schingoethe, M. J. Brouk, and G. A Stegeman. 1998. Systems to evaluate the protein quality of diets fed to lactating cows. J. Dairy Sci. 81:1046-1061.

25. Plaizier, J. C., J.-P. Walton, and B. W. McBride. 2001. Effect of post-ruminal infusion of glutamine on plasma amino acids, milk yield and composition in lactating dairy cows. Can. J. Anim. Sci. 81:229-235.

26. Raggio, G., G. E. Lobley, S. Lemosquet, H. Rulquin, and H. Lapierre. 2006. Effect of casein and propionate supply on whole body protein metabolism in lactating dairy cows. Can. J. Anim. Sci 86:81-89.

27. Richter, M., J. Svobodova, L. Krizova, J. Trinacty, and P. Homolka. 2010. Effect of duodenal infusions of leucine on milk yield and plasma amino acids in dairy cows. Czech J. Anim. Sci. 55:351-358.

28. Schei, I., A. Danfaer, I. A. Boman, and H. Volden. 2007. Postruminal or intravenous infusion of carbohydrates or amino acids to dairy cows 1 . Late lactation. Animal 1:501-514.

29. Schei, I., A. Danfaer, L. T. Myland, and H. Volden. 2007. Postruminal or intravenous infusion of carbohydrates or amino acids to dairy cows 2. Early lactation. Animal 1:515-522.

30. Spires, H. R., J. H. Clark, R. G. Derrig, and C. L. Davis. 1975. Milk production and nitrogen utilization in response to postruminal infusion of sodium caseinate in lactating cows. J. Nutr. 105:1111-1121.

31. Yang, C.-M. J., D. J. Schingoethe, and D. P. Casper. 1986. Protected methionine and heat-treated soybean meal for high producing dairy cows. J. Dairy Sci. 69:2348-2357. 